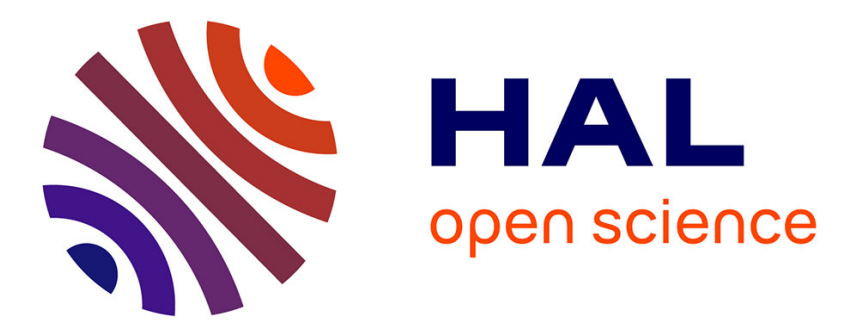

\title{
NO2 columns in the western United States observed from space and simulated by a regional chemistry model and their implications for NOx emissions
}

S.-W. Kim, A. Heckel, G.J. Frost, A. Richter, J. Gleason, J.P. Burrows, S. Mckeen, E.-Y. Hsie, Claire Granier, M. Trainer

\section{To cite this version:}

S.-W. Kim, A. Heckel, G.J. Frost, A. Richter, J. Gleason, et al.. NO2 columns in the western United States observed from space and simulated by a regional chemistry model and their implications for NOx emissions. Journal of Geophysical Research: Atmospheres, 2009, 114 (D11), pp.D11301. 10.1029/2008JD011343 . hal-00380106

\section{HAL Id: hal-00380106 https://hal.science/hal-00380106}

Submitted on 25 Feb 2016

HAL is a multi-disciplinary open access archive for the deposit and dissemination of scientific research documents, whether they are published or not. The documents may come from teaching and research institutions in France or abroad, or from public or private research centers.
L'archive ouverte pluridisciplinaire HAL, est destinée au dépôt et à la diffusion de documents scientifiques de niveau recherche, publiés ou non, émanant des établissements d'enseignement et de recherche français ou étrangers, des laboratoires publics ou privés. 


\title{
$\mathrm{NO}_{2}$ columns in the western United States observed from space and simulated by a regional chemistry model and their implications for $\mathrm{NO}_{\mathrm{x}}$ emissions
}

\author{
S.-W. Kim, ${ }^{1,2}$ A. Heckel, ${ }^{3,4}$ G. J. Frost,,${ }^{1,2}$ A. Richter, ${ }^{3}$ J. Gleason, ${ }^{5}$ J. P. Burrows, ${ }^{3,6}$ \\ S. McKeen, ${ }^{1,2}$ E.-Y. Hsie, ${ }^{1,2}$ C. Granier, ${ }^{1,2,7,8}$ and M. Trainer ${ }^{1}$ \\ Received 22 October 2008; revised 27 February 2009; accepted 9 March 2009; published 3 June 2009.
}

[1] There are many isolated sources of $\mathrm{NO}_{\mathrm{x}}$ emissions across the western United States, including electrical power generation plants and urban areas. In this manuscript, two satellite instruments measuring $\mathrm{NO}_{2}$ vertical columns over these sources and an atmospheric chemical-transport model are used to evaluate bottom-up $\mathrm{NO}_{\mathrm{x}}$ emission inventories, model assumptions, and satellite retrieval algorithms. We carried out simulations with the Weather Research and Forecasting-Chemistry (WRF-Chem) model for the western U.S. domain during the summer of 2005 using measured power plant $\mathrm{NO}_{\mathrm{x}}$ emissions. Model $\mathrm{NO}_{2}$ vertical columns are compared with a retrieval of the Scanning Imaging Absorption Spectrometer for Atmospheric Chartography (SCIAMACHY) satellite instrument data by the University of Bremen and retrievals of the Ozone Monitoring Instrument (OMI) data by the U.S. National Aeronautics and Space Administration (NASA) and a modified version of the NASA OMI retrieval produced by the University of Bremen. For areas dominated by power plant $\mathrm{NO}_{\mathrm{x}}$ emissions, the model $\mathrm{NO}_{2}$ columns serve as a comparison standard for satellite retrievals because emissions are continuously monitored at all large U.S. power plants. An extensive series of sensitivity tests of the assumptions in both the satellite retrievals and the model are carried out over the Four Corners and San Juan power plants, two adjacent facilities in the northwest corner of New Mexico that together represent the largest $\mathrm{NO}_{\mathrm{x}}$ point source in the United States. Overall, the SCIAMACHY and OMI $\mathrm{NO}_{2}$ columns over western U.S. power plants agree well with model $\mathrm{NO}_{2}$ columns, with differences between the two being within the variability of the model and satellite. In contrast to regions dominated by power plant emissions, model $\mathrm{NO}_{2}$ columns over large urban areas along the U.S. west coast are approximately twice as large as satellite $\mathrm{NO}_{2}$ columns from SCIAMACHY and OMI retrievals. The discrepancies in urban areas are beyond the sensitivity ranges in the model simulations and satellite observations, implying overestimates of these cities' bottom-up $\mathrm{NO}_{\mathrm{x}}$ emissions, which are dominated by motor vehicles. Taking the uncertainties in the satellite retrievals into account, our study demonstrates that the tropospheric columns of $\mathrm{NO}_{2}$ retrieved from space-based observations of backscattered solar electromagnetic radiation can be used to evaluate and improve bottom-up emission inventories.

Citation: Kim, S.-W., A. Heckel, G. J. Frost, A. Richter, J. Gleason, J. P. Burrows, S. McKeen, E.-Y. Hsie, C. Granier, and M. Trainer (2009), $\mathrm{NO}_{2}$ columns in the western United States observed from space and simulated by a regional chemistry model and their implications for $\mathrm{NO}_{\mathrm{x}}$ emissions, J. Geophys. Res., 114, D11301, doi:10.1029/2008JD011343.

\footnotetext{
${ }^{1}$ Chemical Sciences Division, Earth System Research Laboratory, NOAA, Boulder, Colorado, USA.

${ }^{2}$ Cooperative Institute for Research in Environmental Sciences, University of Colorado, Boulder, Colorado, USA.

${ }^{3}$ Institute of Environmental Physics and Institute of Remote Sensing, University of Bremen, Bremen, Germany.

${ }^{4}$ Department of Geography, Swansea University, Swansea, UK.

${ }^{5}$ Laboratory for Atmospheres, NASA Goddard Space Flight Center, Greenbelt, Maryland, USA.

${ }^{6}$ Center for Ecology and Hydrology, Wallingford, UK.

${ }^{7}$ Université Pierre et Marie Curie, UMR7620, Paris, France.

${ }^{8}$ Service d'Aéronomie, UMR7620, CNRS, Paris, France.

\section{Introduction}

[2] Nitrogen oxides $\left(\mathrm{NO}_{\mathrm{x}}=\mathrm{NO}+\mathrm{NO}_{2}\right)$ in the troposphere are formed by fossil fuel combustion, biomass burning, soil emissions, and lightning processes [Yevich and Logan, 2003; Galloway et al., 2004; Bertram et al., 2005; Jaeglé et al., 2005]. $\mathrm{NO}_{\mathrm{x}}$ and volatile organic compounds (VOCs) are the main precursors of ozone, a major pollutant in the troposphere and a greenhouse gas playing an important role in the Earth's radiation budget. Nitric acid, formed in the oxidation of $\mathrm{NO}_{\mathrm{x}}$, can lead to particulates that 
in the western United States where sulfate concentrations are relatively small. Nitric acid is removed by wet scavenging and dry deposition, affecting the productivity and diversity of terrestrial ecosystems and disrupting aquatic ecosystem function [Dentener et al., 2006]. Gaseous $\mathrm{NO}_{2}$ is an absorber of solar radiation that directly impacts the radiation budget [Solomon et al., 1999].

[3] Quantification of $\mathrm{NO}_{\mathrm{x}}$ emissions is necessary in order to infer their impacts on atmospheric chemistry and thereby on the Earth system in the long term. Emission inventories of $\mathrm{NO}_{\mathrm{x}}$ are a key part of atmospheric chemical-transport models that simulate ozone and relevant tracers. There are numerous studies reporting worldwide increases in $\mathrm{NO}_{\mathrm{x}}$ emissions resulting from continually expanding human activities such as power generation, motor vehicle use, and the application of soil fertilizer [Galloway et al., 2004, and references therein]. More recently, reductions in $\mathrm{NO}_{\mathrm{x}}$ emissions on a regional scale resulting from the U.S. Environmental Protection Agency's (EPA's) emission controls at eastern U.S. power plants have been demonstrated [Frost et al., 2006; Kim et al., 2006]. However, accurate quantification of absolute $\mathrm{NO}_{\mathrm{x}}$ emissions from anthropogenic or natural sources is difficult. "Bottom-up" inventories based on detailed source information, measured and/or estimated emission factors, and complicated activity calculations are inevitably subject to large uncertainties.

[4] During the past decade, observations of atmospheric nitrogen dioxide $\left(\mathrm{NO}_{2}\right)$ from polar-orbiting satellites have provided a powerful new tool to investigate $\mathrm{NO}_{\mathrm{x}}$ emissions [Bovensmann et al., 1999; Burrows et al., 1999; Levelt et al., 2006]. Because of the relatively short lifetime of $\mathrm{NO}_{\mathrm{x}}$ in the troposphere, particularly in summer, spatial distributions of $\mathrm{NO}_{2}$ vertical columns map out $\mathrm{NO}_{\mathrm{x}}$ source regions. Space-based observations have been utilized to improve $\mathrm{NO}_{\mathrm{x}}$ emission inventories at global and regional scales [Martin et al., 2003b; Jaeglé et al., 2005; Konovalov et al., 2006; Martin et al., 2007] and to detect weekly cycles and year-to-year changes in $\mathrm{NO}_{\mathrm{x}}$ emissions [Beirle et al., 2003; Richter et al., 2005; van der A et al., 2006; Kim et al., 2006; van der $A$ et al., 2008].

[5] While tropospheric $\mathrm{NO}_{2}$ columns retrieved from measurements by instrumentation on orbiting satellites are widely used, an assessment of their accuracy is complex. This complexity arises from the need to convert the measurement of the slant column absorption to a tropospheric vertical column by taking into account the $\mathrm{NO}_{2}$ in the stratosphere and the penetration and transfer of electromagnetic radiation in the atmosphere. There have been several studies addressing the potential sources of systematic errors in satellite retrievals. Boersma et al. [2004] analyzed the assumptions used in the tropospheric $\mathrm{NO}_{2}$ retrieval from the Global Ozone Monitoring Experiment (GOME) satellite instrument and found $35-60 \%$ uncertainties in tropospheric $\mathrm{NO}_{2}$ columns over regions with a large contribution of the troposphere to the total column. van Noije et al. [2006] reported significant differences among three independent satellite $\mathrm{NO}_{2}$ retrievals from GOME observations and indicated that the retrieval differences resulted from assumptions about clouds, surface albedo, profile shape and aerosols as well as stratosphere-troposphere separation. Recently, the resolution of terrain height on the satellite
$\mathrm{NO}_{2}$ retrieval over complex terrain was addressed [Schaub et al., 2007].

[6] Interpretation of satellite observations of tropospheric $\mathrm{NO}_{2}$ generally requires the use of an atmospheric chemicaltransport model. This model calculates the shape of the $\mathrm{NO}_{2}$ vertical profile in each grid cell of its domain. The $\mathrm{NO}_{2}$ profile is one of several quantities needed to construct an air mass factor (AMF) [Palmer et al., 2001] that converts the retrieved tropospheric slant column (SC) to a tropospheric vertical column (VC),

$$
\mathrm{VC}=\mathrm{SC} / \mathrm{AMF}
$$

Chemical-transport models also simulate tropospheric $\mathrm{NO}_{2}$ vertical columns, which can then be compared to the satellite-retrieved vertical columns. Typically satellite data are retrieved using the output of global models with relatively coarse horizontal resolutions (grid cells of a few degrees latitude and longitude) in order to efficiently produce a global data set with consistent input assumptions.

[7] Since 2002, finer-scale observations of $\mathrm{NO}_{2}$ than those from GOME have become available, including measurements by the Scanning Imaging Absorption Spectrometer for Atmospheric Chartography (SCIAMACHY) and the Ozone Monitoring Instrument (OMI). As the spatial resolution of satellite instruments has evolved, the need has arisen for higher-resolution regional atmospheric chemicaltransport models to interpret these observations. The combination of these newer instruments and regional models allows us to explore regional to local-scale air quality. In particular, the smaller spatial footprint of the newer satellite instruments offers the possibility of differentiating the pollution plumes from individual sources, such as power plants and urban areas.

[8] These sector-specific emission evaluations can benefit from the fact that most U.S. power plants employ continuous emissions monitoring systems (CEMS). CEMS directly measure the concentrations of $\mathrm{NO}_{\mathrm{x}}, \mathrm{SO}_{2}$, and $\mathrm{CO}_{2}$ and the mass flow rates in the power plant's exhaust stacks, from which mass emission rates are calculated and reported quarterly to the EPA [U.S. Environmental Protection Agency, 2004]. CEMS measurements of these pollutant emissions represent the most accurate part of the U.S. emissions database [Frost et al., 2006]. CEMS $\mathrm{NO}_{\mathrm{x}}, \mathrm{SO}_{2}$, and $\mathrm{CO}_{2}$ emissions data from numerous power plants have been extensively compared to aircraft observations of concentration ratios and absolute flux determinations in the plumes downwind of the plants [Ryerson et al., 1998; Frost et al., 2006], and these two approaches are in good agreement. CEMS data, aircraft observations and satellite retrievals have also demonstrated substantial reductions in eastern U.S. power plant $\mathrm{NO}_{\mathrm{x}}$ emissions since pollution regulations went into effect at these facilities [Frost et al., 2006; Kim et al., 2006].

[9] In contrast, most western U.S. power plants have not yet undergone extensive $\mathrm{NO}_{\mathrm{x}}$ pollution controls. According to CEMS data, the Four Corners and San Juan power plants in New Mexico were two of the highest $\mathrm{NO}_{\mathrm{x}}$-emitting power plants in the U.S in 2005. $\mathrm{NO}_{2}$ plumes from these and other western U.S. power plants are clearly observed from space [Beirle et al., 2004], because they are relatively isolated from other large $\mathrm{NO}_{\mathrm{x}}$ sources. Because their $\mathrm{NO}_{\mathrm{x}}$ 
emissions are measured by $\mathrm{CEMS}, \mathrm{NO}_{2}$ columns simulated by an atmospheric chemical-transport model above these isolated western power plants have less uncertainty than those from other $\mathrm{NO}_{\mathrm{x}}$ sources, providing an excellent opportunity to evaluate satellite-retrieved $\mathrm{NO}_{2}$ columns.

[10] The two goals of the present study are (1) to evaluate fine-resolution satellite $\mathrm{NO}_{2}$ observations from SCIAMACHY and OMI with a regional-scale model over western U.S. power plants and (2) to explore the possibility of using these satellite $\mathrm{NO}_{2}$ columns to quantify uncertainties in inventory $\mathrm{NO}_{\mathrm{x}}$ emissions from urban and mobile sources. We employ the Weather Research and Forecasting-Chemistry (WRF-Chem) model to simulate $\mathrm{NO}_{2}$ columns over the western United States. SCIAMACHY data retrieved by the University of Bremen (UB) and two versions of the OMI data, one retrieved by the National Aeronautics and Space Administration (NASA) and the other a modification of the NASA OMI retrieval produced by UB, are compared to the model results.

[11] The manuscript is organized as follows. The overall method is described in section 2 in three parts. First the satellite instruments, measurements, and retrievals are summarized. Next the WRF-Chem model is introduced and the specific simulations are described. The results and discussion are given in section 3, which is organized into four subsections. Section 3.1 examines the distribution of $\mathrm{NO}_{2}$ columns from three satellite retrievals in the domain of interest for the summer of 2005. In sections 3.2 and 3.3, summer 2005 satellite $\mathrm{NO}_{2}$ columns from power plants and urban areas are compared with the model $\mathrm{NO}_{2}$ columns, and the implications of these comparisons for $\mathrm{NO}_{\mathrm{x}}$ emissions are discussed. In section 3.4, we examine year-to-year trends in the satellite $\mathrm{NO}_{2}$ columns and discuss how these trends help in interpreting the summer 2005 satellite-model differences. In section 4 we present our conclusions.

\section{Methods}

\subsection{Satellite Retrievals of $\mathrm{NO}_{2}$ Columns}

\subsubsection{SCIAMACHY}

[12] The trace gas sensor SCIAMACHY onboard European Space Agency's ENVISAT-1 satellite in Sun-synchronous orbit provides a smooth continuation of measurements performed by its predecessor instrument, GOME, onboard the ERS-2 satellite. The enhanced capabilities of SCIAMACHY in measuring $\mathrm{NO}_{2}$ include increased horizontal resolution $(60 \mathrm{~km}$ across-track direction $\times 30 \mathrm{~km}$ alongtrack direction) and a limb-nadir matching scan for obtaining the vertical structure of $\mathrm{NO}_{2}$ as well as the $\mathrm{NO}_{2}$ column amount. The satellite overpass time is about 1000 local standard time (LST) and global coverage is achieved in 6 days at the equator.

[13] The retrieval of SCIAMACHY $\mathrm{NO}_{2}$ consists of three steps: (1) spectral fitting, (2) separation of stratospheric and tropospheric $\mathrm{NO}_{2}$, and (3) conversion of slant columns to vertical columns [Richter and Burrows, 2002; Boersma et al., 2004; Richter et al., 2005]. The first two steps determine the tropospheric slant column of $\mathrm{NO}_{2}$. The last step converts slant column to vertical column using an AMF [Richter and Burrows, 2002] that is calculated by a radiative transfer model [Rozanov et al., 1997]. The UB retrieval uses the Differential Optical Absorption Spectroscopy (DOAS) method in the 425-450 nm wavelength region for spectral fitting and the reference sector method for stratospheretroposphere separation. In the reference sector method, the slant column over the clean Pacific Ocean is subtracted from the total column to get the tropospheric slant column. The SCIATRAN radiative transfer code is used to generate a look-up table for the AMF as function of observation geometry, altitude, surface height, albedo, and aerosol. Aerosol corrections were applied using the Low Resolution Transmission Model (LOWTRAN) aerosol types [Shettle and Fenn, 1979]: "maritime" over oceans, "rural" over land, and "urban" over regions with high $\mathrm{CO}_{2}$ emissions based on the EDGAR database (http://www.mnp.nl/edgar/). A priori $\mathrm{NO}_{2}$ profiles in the standard evaluation are adopted from monthly mean MOZART-2 model simulations for 1997 with a horizontal resolution of $2.8^{\circ} \times 2.8^{\circ}$ [Horowitz et al., 2003]. The temperature dependence of the $\mathrm{NO}_{2}$ absorption cross section is also accounted for in the calculation of the AMF, as described by Boersma et al. [2004]. Surface albedo is based on GOME observations [Koelemeijer et al., 2003]. The sensitivity of the retrieval to the a priori $\mathrm{NO}_{2}$ profile and aerosol loading is examined in section 3. $\mathrm{NO}_{2}$ columns retrieved using the WRF-Chem $\mathrm{NO}_{2}$ profiles are calculated assuming both LOWTRAN aerosols and no aerosols. Cloud fraction is defined as the normalized intensity of radiance, that is, the deviation in intensity in a given scene from that in a reference clear scene normalized by the deviation in intensity in a fully cloud covered scene from the same reference value. The data are selected for low cloud fraction, but the impact of remaining clouds on the retrieval for a partially cloudy scene is not considered.

[14] Five versions of the UB SCIAMACHY data are considered here (Table 1). Three versions of the swath (ungridded orbital) data with different $\mathrm{NO}_{2}$ profile and aerosol assumptions are used for the model and satellite comparisons and retrieval sensitivity analysis for the year 2005 (data version 3 in Table 1). Satellite scenes with cloud fraction $>0.15$ in the swath data are discarded for these purposes. The swath data using one set of these assumptions are aggregated on a $15 \mathrm{~km} \times 15 \mathrm{~km}$ grid and averaged over the entire summer of 2005 to produce the western U.S. map (data version 2). For the trend analyses, the monthly mean gridded data $\left(0.25^{\circ} \times 0.25^{\circ}\right)$ are used, and grid cells with cloud fraction $>0.2$ are removed (data version 1 ). The monthly mean data sets are standard products available for the years 2003-2007. Although a slightly different cloud fraction is used for filtering the data in each product, the same criterion is applied to all years of a particular data set when deriving the $\mathrm{NO}_{2}$ column trends.

\subsubsection{OMI}

[15] OMI is an instrument onboard NASA's Earth Observing System Aura satellite launched in July 2004 [Levelt et al., 2006]. The wide field of view of the nadir-pointing telescope $\left(114^{\circ}\right)$ gives OMI a swath width of $2600 \mathrm{~km}$ and provides daily global coverage with a high horizontal resolution. For the channel in which $\mathrm{NO}_{2}$ is observed in global observation mode, the pixel size in the swath direction increases from $13 \mathrm{~km} \times 24 \mathrm{~km}$ (along $\times$ across track) at the exact nadir position to about $13 \mathrm{~km} \times 150 \mathrm{~km}$ at the outermost swath angle $\left(57^{\circ}\right)$. For this study, the outermost pixels are not considered, and the pixels used 
Table 1. Summary of Satellite Data Sets Used in This Study ${ }^{\mathrm{a}}$

\begin{tabular}{|c|c|c|c|c|c|}
\hline Data Name & $\begin{array}{l}\text { Monthly } \\
\text { Mean }\end{array}$ & Gridded/Swath & $\begin{array}{c}\text { Cloud } \\
\text { Filtering } \\
\text { Criterion }\end{array}$ & $\begin{array}{c}\text { A Priori } \\
{\text { Model } \mathrm{NO}_{2}} \\
\text { Profile }\end{array}$ & $\begin{array}{c}\text { A Priori } \\
\text { Aerosol } \\
\text { Assumption }\end{array}$ \\
\hline \multicolumn{6}{|c|}{ Trend Analysis } \\
\hline UB-SCIA 1 & Yes & Grid $\left(0.25^{\circ} \times 0.25^{\circ}\right)$ & 0.2 & MOZART & LOWTRAN \\
\hline UB-OMI 1 & Yes & Grid & 0.2 & MOZART & LOWTRAN \\
\hline NASA-OMI 1 & Yes & $\left(0.125^{\circ} \times 0.125^{\circ}\right)$ & 0.3 & GEOS-Chem & No aerosol \\
\hline \multicolumn{6}{|c|}{ Map of $\mathrm{NO}_{2}$} \\
\hline UB-SCIA 2 & No & Grid $\left(0.25^{\circ} \times 0.25^{\circ}\right)$ & 0.15 & MOZART & LOWTRAN \\
\hline UB-OMI 2 & No & Grid $(15 \mathrm{~km} \times 15 \mathrm{~km})$ & 0.15 & MOZART & LOWTRAN \\
\hline NASA-OMI 2 & No & Grid $(15 \mathrm{~km} \times 15 \mathrm{~km})$ & 0.15 & GEOS-Chem & No aerosol \\
\hline \multicolumn{6}{|c|}{ Comparison With Model and Sensitivity Test } \\
\hline UB-SCIA 3a & No & Swath (ungridded) & 0.15 & MOZART & LOWTRAN \\
\hline UB-SCIA 3b & No & Swath (ungridded) & 0.15 & WRF-Chem & LOWTRAN \\
\hline UB-SCIA 3c & No & Swath (ungridded) & 0.15 & WRF-Chem & No aerosol \\
\hline UB-OMI 3a & No & Swath (ungridded) & 0.15 & MOZART & LOWTRAN \\
\hline UB-OMI 3b & No & Swath (ungridded) & 0.15 & WRF-Chem & LOWTRAN \\
\hline UB-OMI 3c & No & Swath (ungridded) & 0.15 & WRF-Chem & No aerosol \\
\hline NASA-OMI 3 & No & Swath (ungridded) & 0.15 & GEOS-Chem & No aerosol \\
\hline
\end{tabular}

${ }^{\text {a }}$ Standard product in each retrieval is in boldface.

vary in size from $13 \mathrm{~km} \times 24 \mathrm{~km}$ to $13 \mathrm{~km} \times 30 \mathrm{~km}$. The time of an OMI overpass is about 1330 LST.

\subsubsection{NASA OMI}

[16] The OMI measured reflectance spectrum, in the wavelength range 405 to $465 \mathrm{~nm}$, is fit using the DOAS technique to get the slant column density [Chance, 2002; Bucsela et al., 2006]. To separate the stratospheric and tropospheric $\mathrm{NO}_{2}$ contributions, the NASA OMI algorithm uses the different spatial scales of stratospheric and tropospheric $\mathrm{NO}_{2}$. Tropospheric $\mathrm{NO}_{2}$ occurs on local- and regional-scale features, while stratospheric $\mathrm{NO}_{2}$ has very large, planetary wave-scale features. The algorithm uses these differences to spatially filter the data to identify regions of enhanced tropospheric $\mathrm{NO}_{2}$. This separation is carried out in three steps. First, an initial vertical column is calculated using an AMF appropriate to unpolluted conditions. Second, for each day, the global $\mathrm{NO}_{2}$ initial data are fit to a wave-2 Fourier series. This smoothed field is subtracted from the initial data. The areas of enhanced tropospheric $\mathrm{NO}_{2}$ are clearly identified in the difference field. The third step is to calculate a new tropospheric column using an AMF computed using an enhanced tropospheric $\mathrm{NO}_{2}$ profile. In the last step, $5 \%$ of smoothed fields (background $\mathrm{NO}_{2}$ columns) are added to polluted (or unpolluted) columns to get the final tropospheric $\mathrm{NO}_{2}$ columns, in order to account for an assumed upper tropospheric background level. All the AMFs are calculated using the TOMRAD radiative transfer code [Dave, 1965]. For the initial case, average NCEP temperatures and standard $\mathrm{NO}_{2}$ profiles are used for the AMF calculations. Annual average $\mathrm{NO}_{2}$ profiles from the GEOS-Chem model [Bey et al., 2001; Martin et al., 2003a; Park et al., 2004] are used in the calculation of the AMF for polluted cases. The AMF for a partly cloudy scene is obtained by accounting for the cloud fraction, cloud top height and radiances for cloudy and clear scenes [Chance, 2002; Bucsela et al., 2006]. As mentioned by Boersma et al. [2004], errors in cloud fractions of \pm 0.05 can give up to $30 \%$ errors in $\mathrm{NO}_{2}$ columns for highly polluted regions. Errors in cloud top height may affect retrievals in cases where pollution exists within the cloud layer. Thus, for polluted regions, uncertainties in cloud fractions determined from the radiance closure method and cloud heights retrieved from the OMI $\mathrm{O}_{2}-\mathrm{O}_{2}$ absorption can affect the retrieved $\mathrm{NO}_{2}$ column (ghost column) significantly. Our study did not include a ghost column in the analysis. GOME data [Koelemeijer et al., 2003] are used to derive surface albedo. Aerosol effects are not considered in the NASA OMI AMF calculations.

[17] For the model and satellite comparisons in 2005, fine-resolution swath data (collection 3, level 2) scenes with pixel numbers between 20 and 40 and cloud fraction $<0.15$ are used. Seasonal averages of the swath data aggregated on a $15 \mathrm{~km} \times 15 \mathrm{~km}$ grid are used in the western U.S. map in Figure 3. The $0.25^{\circ} \times 0.25^{\circ}$ monthly mean gridded data (collection 3, level 3) with cloud fractions $<0.3$ available for each year 2005-2007 on the Internet are used in the trend analyses. Different cloud fractions are used to filter the cloudy scenes in different data sets. However, a consistent cloud fraction is applied to all years of a specific analysis. Details about the versions of NASA OMI data used in this study are given in Table 1. NASA OMI data have been validated with several ground-based and aircraft-observed $\mathrm{NO}_{2}$ columns, which show reasonable agreement between the NASA OMI retrievals and several remote-sensing and in situ validation measurement [Bucsela et al., 2008; Celarier et al., 2008; Wenig et al., 2008].

\subsubsection{University of Bremen OMI}

[18] The UB OMI data use the slant columns provided by the operational NASA OMI product (collection 3). However, the stratospheric correction and tropospheric AMF calculations in the UB OMI retrievals are different from those of NASA OMI. UB OMI processing follows the process used for the UB SCIAMACHY retrievals. The reference sector method is used to separate stratospheric and tropospheric columns. GOME data are used to get surface albedo. As is done for SCIAMACHY, the sensitivity of the OMI retrieval to the $\mathrm{NO}_{2}$ profile and aerosol is assessed in section 3. The AMF in the standard retrieval is calculated using the 
Table 2. WRF-Chem Model Configuration Used in This Study

\begin{tabular}{ll}
\hline \multicolumn{1}{c}{ Parameter } & \multicolumn{1}{c}{ Options } \\
\hline Advection scheme & RK3 [Wicker and Skamarock, 2002; \\
& Skamarock, 2006] \\
Microphysics & Single moment 5 class [Hong et al., 2004] \\
Longwave radiation & RRTM [Mlawer et al., 1997] \\
Shortwave radiation & Simple shortwave scheme [Dudhia, 1989] \\
Surface layer & Similarity theory [Paulson, 1970; \\
& Dyer and Hicks, 1970] \\
Land-surface model & Noah LSM [Chen and Dudhia, 2001] \\
Boundary layer scheme & YSU [Hong et al., 2006] \\
Cumulus parameterization & Grell-Devenyi ensemble \\
& [Grell and Devenyi, 2002] \\
Photolysis scheme & TUV [Madronich, 1987] \\
Gas phase chemistry & RADM2 [Stockwell et al., 1990], \\
& RACM-ESRL \\
Aerosols & MADE [Ackermann et al., 1998], \\
& SORGAM [Schell et al., 2001] \\
\hline
\end{tabular}

MOZART $\mathrm{NO}_{2}$ profile and LOWTRAN aerosol assumptions. In the sensitivity studies, the AMF is calculated on the basis of WRF-Chem $\mathrm{NO}_{2}$ vertical profiles assuming either LOWTRAN aerosols or no aerosol. The swath data with cloud fraction $<0.15$ are used for model and satellite comparisons for the year 2005. The UB OMI product uses the same cloud fraction as the NASA OMI $\mathrm{NO}_{2}$ product. Only fine-resolution scenes with pixel number between 20 and 40 are used as with NASA OMI data. Trend analyses use $0.125^{\circ} \times 0.125^{\circ}$ monthly mean grid data with cloud fraction $<0.2$, the same value as in the trend analyses with the UB SCIAMACHY product. See Table 1 for more details.

\subsection{WRF-Chem Model Simulations of $\mathrm{NO}_{2}$ Columns}

\subsubsection{Model Setup}

[19] The WRF-Chem model is based on the nonhydrostatic mesoscale numerical weather prediction model, the WRF community model, developed at the National Center for Atmospheric Research in collaboration with several research institutes. WRF is an operational forecasting model that is flexible and computationally efficient, while offering the advances in physics, numerics, and data assimilation contributed by the research community [Skamarock et al., 2007]. The WRF-Chem model system is "online" in the sense that all processes affecting the gas phase and aerosol species are calculated in lock step with the meteorological dynamics [Grell et al., 2005]. Meteorological initial and boundary conditions are taken from the National Centers for Environmental Prediction (NCEP) Global Forecast System model analysis fields. Gas phase chemistry is discussed in section 2.2.3. Lateral boundary conditions for ozone and its precursors are the same as in work by McKeen et al. [2002] and are based on averages of midlatitude aircraft profiles from several field studies over the eastern Pacific Ocean. Biogenic emissions are calculated at each time step using the Biogenic Emissions Inventory System (BEIS3.11) algorithm (http://www.epa.gov/asmdnerl/biogen.html). Anthropogenic emissions used in this study are described in section 2.2.2. The horizontal domain of $200 \times 140$ grid cells has a grid spacing of $15 \mathrm{~km}$ and is centered at $111.0^{\circ} \mathrm{W}$ and $38.0^{\circ} \mathrm{N}$. The spacing of the model's 35 vertical levels is about $40 \mathrm{~m}$ near the surface and increases to approximately $1.5 \mathrm{~km}$ at the top of the domain (at $\sim 18 \mathrm{~km}$ ). A summary of physical parameterization options is shown in Table 2.

\subsubsection{Emission Inventories}

[20] The WRF-Chem emissions for all sources except power plants are represented by the EPA 1999 National Emission Inventory version 3 (NEI99). A detailed discussion of the NEI99 processing is given by Frost et al. [2006]. Briefly, hourly emissions of $\mathrm{NO}_{\mathrm{x}}, \mathrm{SO}_{2}, \mathrm{CO}$, total and speciated VOCs, $\mathrm{NH}_{3}$, total and speciated PM2.5, and total PM10 were prepared for an average day in the 1999 summer ozone season (1 May to 30 September) on a $4 \mathrm{~km} \times 4 \mathrm{~km}$ grid. These emissions were then projected onto the $15 \mathrm{~km}$ grid used in the WRF-Chem simulations.

[21] We developed a general algorithm to update the emissions of $\mathrm{NO}_{\mathrm{x}}$ and $\mathrm{SO}_{2}$ from all NEI99 point sources that also appear in EPA's national CEMS emission database during the years 1995-2007. About $98 \%$ of the facilities in the CEMS detailed hourly files (ftp://ftp.epa.gov/dmdnload/ emissions/hourly/monthly) and aggregated data reports (http://camddataandmaps.epa.gov/gdm/index.cfm?fuseaction= emissions.wizard) are involved in electric power generation. The WRF-Chem reference simulations discussed in section 3 used CEMS monthly total $\mathrm{NO}_{\mathrm{x}}$ and $\mathrm{SO}_{2}$ emissions for June-August 2005 to create month-specific average daily updates to the 1999 ozone season day emissions of approximately 1000 NEI99 facilities. The facilities with updated emissions represented $64 \%$ and $95 \%$ of the $\mathrm{NO}_{\mathrm{x}}$ emissions from point sources in the NEI99 and 2005 CEMS data sets, respectively. $\mathrm{NO}_{\mathrm{x}}$ and $\mathrm{SO}_{2}$ emissions from facilities appearing in the NEI99 but not in the CEMS data set were left at their 1999 levels. CEMS data from facilities not in the NEI99 were not included in the updated inventory. NEI99 area and mobile source emissions and point source emissions of compounds besides $\mathrm{NO}_{\mathrm{x}}$ and $\mathrm{SO}_{2}$ were not modified and remained at their 1999 ozone season day levels.

[22] In the WRF-Chem reference simulations, monthspecific average daily $\mathrm{NO}_{\mathrm{x}}$ emissions from every U.S. power plant are partitioned for each hour of the day using the same default NEI99 diurnal allocation factor, ignoring the actual daily and hourly fluctuations of $\mathrm{NO}_{\mathrm{x}}$ emissions at specific facilities. This emission inventory is referred to as the "monthly default" emissions. WRF-Chem sensitivity simulations were also performed using the actual daily and hourly CEMS observations at all power plants appearing in the CEMS data set discussed above, hereafter referred to as "real-time" CEMS emissions.

\subsubsection{Chemical Mechanisms}

[23] The WRF-Chem model has various chemical mechanisms available. While RADM2 [Stockwell et al., 1990] has been used most intensively in previous WRF-Chem studies, updates including RACM [Stockwell et al., 1997] and RACM-MIM [Geiger et al., 2003] are also available. We updated the rate coefficients in the RACM-MIM mechanism following the JPL 2006 report [Sander et al., 2006] and other references [Tyndall et al., 2001; Calvert et al., 2002; Orlando et al., 2002]; hereafter we will refer to this updated scheme as RACM-ESRL. All of the above mechanisms were compiled using the KPP method coupled with the WRFChem model (M. Salzmann and M. G. Lawrence, Automatic coding of chemistry solvers in WRF-Chem using KPP, paper presented at 7th WRF/16th MM5 Users' Workshop, National 
Table 3. Summary of WRF-Chem Model Simulations

\begin{tabular}{llll}
\hline Simulations & \multicolumn{1}{c}{ Emissions } & Advection Scheme & $\begin{array}{c}\text { Chemical } \\
\text { Mechanism }\end{array}$ \\
\hline M1 & Monthly default & Positive definite & RACM-ESRL \\
M2 & Real time & Positive definite & RACM-ESRL \\
M3 & Monthly default & Nonpositive definite & RACM-ESRL \\
M4 & Monthly default & Positive definite & RADM2 \\
\hline
\end{tabular}

Center for Atmospheric Research, Boulder, Colorado, 2006, available at http://www.mmm.ucar.edu/wrf/users/ workshops/WS2006/abstracts/Session06/6_4_Salzmann. pdf). Here we present results using RADM 2 and RACMESRL, the oldest and the most updated chemical mechanisms in WRF-Chem, since these mechanisms produce the two extremes in the model $\mathrm{NO}_{2}$ vertical column calculations.

\subsubsection{Advection Schemes}

[24] The advection terms in the WRF model have the form of a flux divergence and are calculated using a RungeKutta third-order accuracy time-splitting integration scheme (RK3) [Wicker and Skamarock, 2002]. The spatial discretizations of flux divergence are accurate to fifth order in the horizontal direction and to third order in the vertical direction. However, this scalar transport scheme does not give positive definite and monotonic advection. A new feature of WRF-Chem version 2.2 is the application of a positive-definite flux renormalization called the positivedefinite (PD) limiter [Skamarock, 2006]. In this study, we tested the RK3 advection scheme with and without the PD limiter. The model simulations with various combinations of emission treatment, chemical mechanism, and advection scheme are summarized in Table 3.

\section{Results and Discussion}

\subsection{Distributions of $\mathrm{NO}_{2}$ Columns}

[25] SCIAMACHY average $\mathrm{NO}_{2}$ columns for the summer of 2005 over the continental United States illustrate that $\mathrm{NO}_{\mathrm{x}}$ emission sources in the eastern half of the country are more densely located than those in the western half (Figure 1). While some cities in the central and southeast United States can be easily identified within the color scale employed in Figure 1, individual cities in the northeastern urban corridor are not readily discernible and instead appear as a single contiguous megacity. In contrast, individual $\mathrm{NO}_{\mathrm{x}}$ sources in the western United States are more isolated, and satellite $\mathrm{NO}_{2}$ column signals can be associated with specific types of sources. As we demonstrate below, $\mathrm{NO}_{2}$ plumes from most western U.S. cities and a number of coal-burning power plants can be clearly identified in the SCIAMACHY columns in Figure 1.

[26] Figure 2 shows the UB SCIAMACHY average summer $2005 \mathrm{NO}_{2}$ columns for the western portion of the United States, and major $\mathrm{NO}_{\mathrm{x}}$ sources are readily identified. We have drawn boxes in Figure 2 to highlight plumes dominated by the $\mathrm{NO}_{\mathrm{x}}$ emissions of 20 electric power generating plants (labeled "P") and 14 major cities (labeled " $C$ ") in this domain. The box locations and sizes were chosen with the intent of capturing the majority of the summer average satellite $\mathrm{NO}_{2}$ column signals over each source of interest while excluding signals from nearby sources. The smallest sampling box size $\left(\mathrm{P} 3,0.375^{\circ}\right.$ latitude $\times 0.75^{\circ}$ longitude) is similar to a SCIAMACHY pixel, encompasses at least 6 OMI pixels in the exact nadir view, and covers at least 8 model grid cells. In sections 3.2 and 3.3, the tropospheric $\mathrm{NO}_{2}$ data products retrieved from the observations of the different instruments will be systematically compared with the model-simulated $\mathrm{NO}_{2}$ columns for these power plant and urban area sampling boxes to evaluate the $\mathrm{NO}_{\mathrm{x}}$ emission inventories of these two types of sources.

[27] Figure 3, with the same spatial domain as Figure 2, compares summer 2005 averages of the NASA and UB OMI $\mathrm{NO}_{2}$ column data sets and the WRF-Chem model results at the time of the OMI overpass. As in the SCIA-

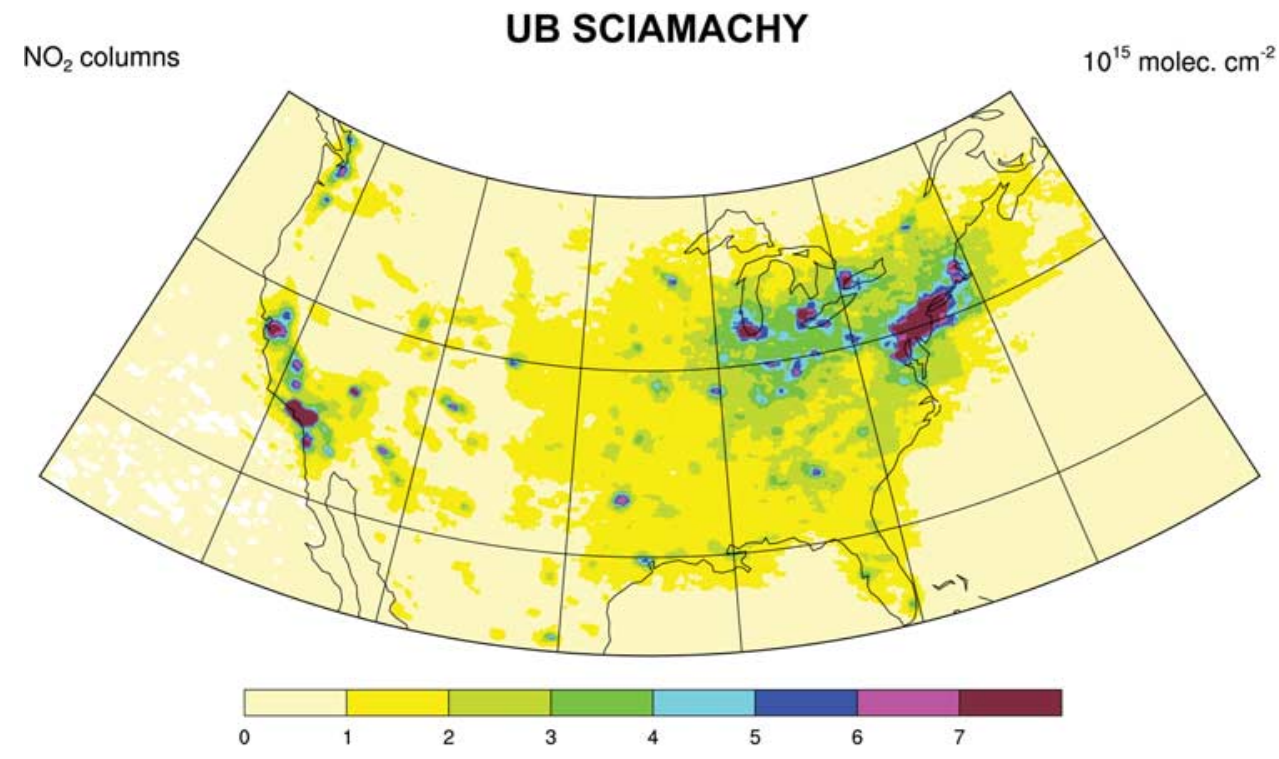

Figure 1. Distributions of average $\mathrm{NO}_{2}$ columns over the continental United States during the summer of 2005 from the University of Bremen (UB) retrievals of the SCIAMACHY satellite instrument. The satellite data set UB-SCIA 1 (see Table 1) was used to construct this image. 


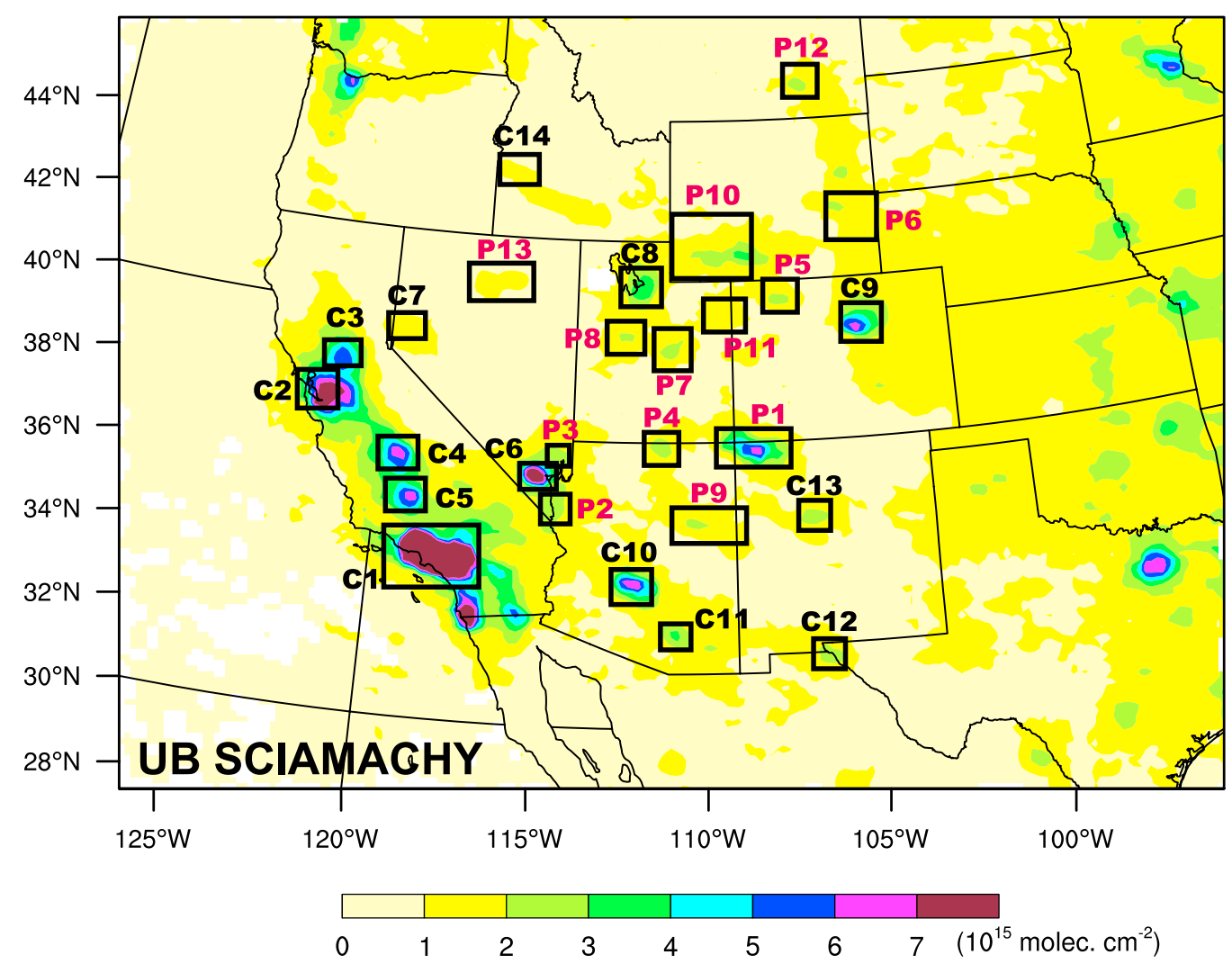

Figure 2. Boxes highlighting plumes from western U.S. power plants and cities overlaid on the UB SCIAMACHY average $\mathrm{NO}_{2}$ columns during the summer of 2005. Labels starting with "P" and "C" indicate power plant and city boxes, respectively. Data set UB-SCIA 2 (Table 1) was used to construct this image. See Tables 4 and 5 for the geographic details of each box. Box labeled P1 here is box P1b in Table 4.

MACHY data (Figure 2), power plant and urban $\mathrm{NO}_{\mathrm{x}}$ sources are clearly seen in the OMI and model columns in Figure 3. NASA OMI $\mathrm{NO}_{2}$ columns (Figure 3a) in remote regions are higher than those from UB OMI (Figure 3b) and the model $\mathrm{NO}_{2}$ columns (Figure 3c). In contrast, UB OMI data show somewhat lower $\mathrm{NO}_{2}$ columns in remote regions compared to the model results. NASA OMI $\mathrm{NO}_{2}$ columns for the major $\mathrm{NO}_{\mathrm{x}}$ sources are greater than those from UB OMI. Model $\mathrm{NO}_{2}$ columns in many urban areas are clearly greater than either of the satellite data sets.

[28] Differences between the two OMI retrievals shown in Figure 3 stem from the different approaches used by UB and NASA to separate stratospheric and tropospheric $\mathrm{NO}_{2}$ columns and to calculate the AMF and the treatment of clouds. As mentioned above, the UB OMI retrieval uses the reference sector method to remove the stratospheric $\mathrm{NO}_{2}$ contribution, while the NASA OMI retrieval applies a planetary wave analysis and smoothing process to filter out stratospheric columns. The reference sector method is expected to give lower columns, because of the assumption that the entire $\mathrm{NO}_{2}$ column over a presumably clean sector (such as the middle of the Pacific Ocean) is due only to $\mathrm{NO}_{2}$ in the stratosphere. There are small amounts of $\mathrm{NO}_{2}$ throughout the remote troposphere, however, and this small remote tropospheric $\mathrm{NO}_{2}$ column is then globally subtracted from the total slant column. In contrast, $5 \%$ of the smoothed background field is added to get tropospheric columns in the NASA OMI data. The differences between the AMF calculations in two OMI retrievals include $\mathrm{NO}_{2}$ vertical profiles derived from different global chemical transport models and different assumptions about aerosol optical thickness and aerosol vertical profiles. As the UB data set does not correct for the residual clouds, it is expected to underestimate $\mathrm{NO}_{2}$ over emission areas.

[29] The comparison of UB SCIAMACHY and UB OMI (or NASA OMI) can give insights into the diurnal variation of $\mathrm{NO}_{\mathrm{x}}$ emissions because of the different satellite overpass times: SCIAMACHY measures at $1000 \mathrm{LT}$ and OMI at 1330 LT. In addition to differences between the UB OMI and NASA OMI retrievals, however, the different numbers of samples in the UB SCIAMACHY and UB OMI products complicate the derivation of diurnal variations in emissions. To confidently deduce these emission variations, the same day's observations of SCIAMACHY and OMI accumulated over several years would need to be examined. This is a topic of interest for further study.

[30] The differences in the three satellite data sets for specific types of $\mathrm{NO}_{\mathrm{x}}$ sources will be investigated in sections 3.2-3.4. While it is important to understand the causes of discrepancies between different satellite retrievals, a detailed examination of each step in these algorithms is beyond the scope of this study. Instead, we use the differences between the three tropospheric $\mathrm{NO}_{2}$ retrievals as a 

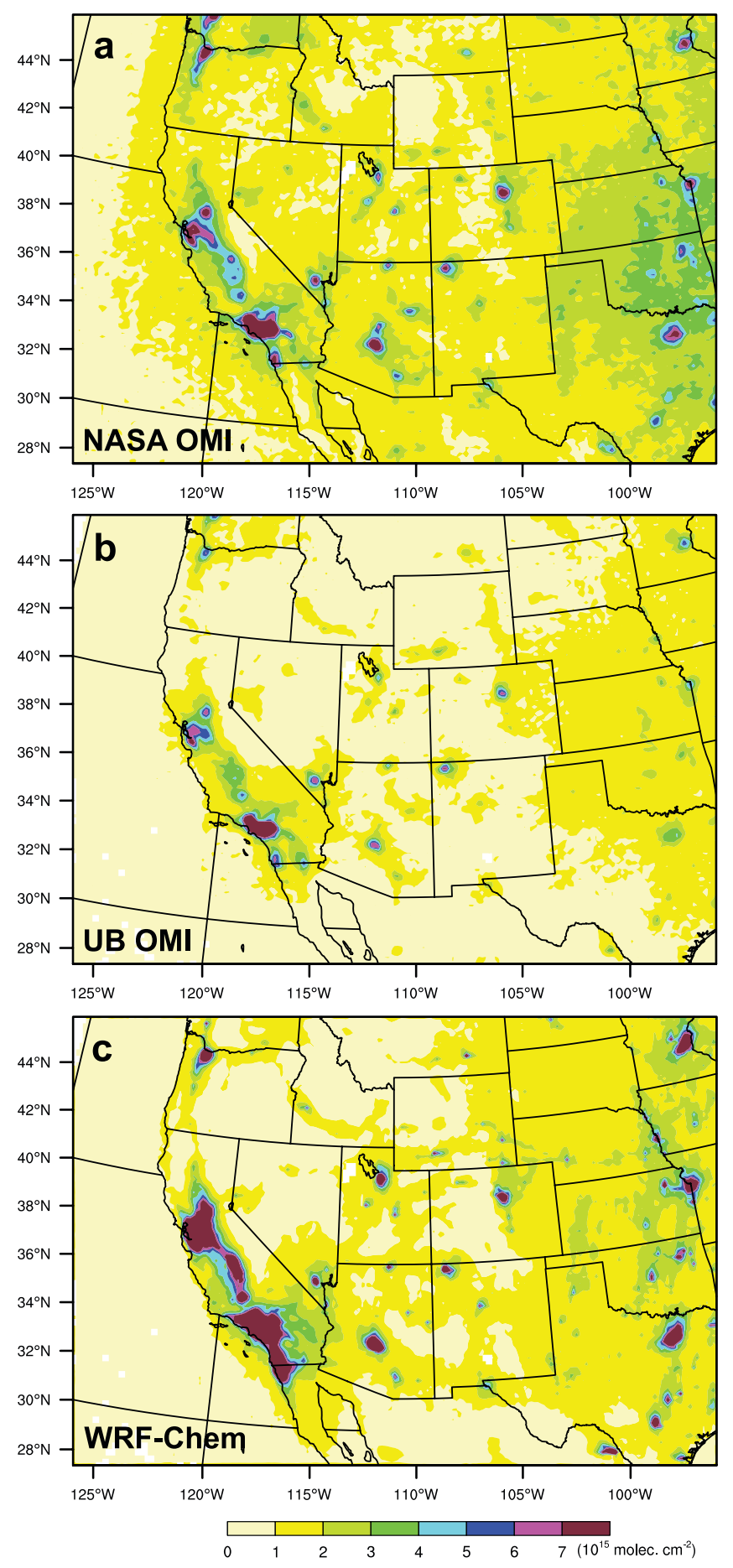

Figure 3. (a) NASA OMI, (b) UB OMI, and (c) WRFChem average $\mathrm{NO}_{2}$ columns during the summer of 2005 for the same domain as Figure 2. Satellite data sets NASA-OMI 2 and UB-OMI 2 (Table 1) and model simulation case M2 (Table 3) were used to construct these images. measure of the range of systematic uncertainties in the satellite data. We then explore the possibility of using these satellite data to evaluate bottom-up emission inventories.

\section{2. $\mathrm{NO}_{2}$ Columns Over Power Plants}

[31] The locations and sizes of the sampling boxes surrounding the power plant plumes are summarized in Table 4. According to CEMS data, Four Corners and San Juan Power Plants (FCSJ) had the highest and tenth highest $\mathrm{NO}_{\mathrm{x}}$ emissions of all U.S power plants during the summer of 2005. The combined $\mathrm{NO}_{2}$ plume from FCSJ (the two plants are separated by only $13 \mathrm{~km}$ ) is the dominant power plant signal in Figure 2 (box P1) and Figure 3. To understand the impact of the size of the sampling box on the model-satellite and satellite-satellite comparisons discussed later in section 3.2.2, we constructed both small $\left(\mathrm{P} 1 \mathrm{a}, 0.5^{\circ}\right.$ latitude $\times 1^{\circ}$ longitude) and large $\left(\mathrm{P} 1 \mathrm{~b}, 1^{\circ}\right.$ latitude $\times 2^{\circ}$ longitude) sampling boxes around the FCSJ $\mathrm{NO}_{2}$ plume (for clarity, only box P1b is shown in Figure 2). $\mathrm{NO}_{2}$ columns over a number of other large coal-burning power plants are highlighted by the boxes labeled with "P" in Figure 2.

3.2.1. Comparison of Summer 2005 Average Columns

[32] Figure 4 compares summer 2005 average $\mathrm{NO}_{2}$ columns for cloud-free conditions from the different satellite instruments/retrievals and those from the model over each power plant box. To systematically compare the satellite data with the model results, the WRF-Chem data are projected on to the daily orbital SCIAMACHY and OMI swaths. Because clouds effectively reflect ultraviolet sunlight, which in turn inhibits the satellite from sensing the boundary layer $\mathrm{NO}_{2}$, cloudy grid cells are then filtered out. Swath data with cloud fraction $<0.15$ are used in the comparisons of the satellite retrievals with the model, ensuring the same number of samples in each comparison. The model results include simulations using either the monthly default or real-time emissions.

[33] Power plant $\mathrm{NO}_{2}$ columns from SCIAMACHY show reasonable agreement with those from the model (Figure 4a). OMI $\mathrm{NO}_{2}$ columns retrieved by the University of Bremen using the same air mass factor approach as the SCIAMACHY retrievals show a similar degree of agreement with the model (Figure 4b). Overall, the mean model results with either set of emissions agree with the means of the two satellite data sets retrieved by UB to within 1 standard deviation. There is a tendency for higher model results than the satellite data. However, the model overestimates are less than $1.5 \times 10^{15}$ (molecule $\mathrm{cm}^{-2}$ ) with an average difference of $5 \times 10^{14}$ (molecule $\mathrm{cm}^{-2}$ ).

[34] $\mathrm{NO}_{2}$ columns from NASA OMI show very good agreement with the model results (Figure 4c). For several power plants, in contrast to the UB SCIAMACHY and OMI data, NASA OMI $\mathrm{NO}_{2}$ columns are higher than the model. The differences between the two retrieval approaches seen in Figure 4 are consistent with those shown in Figure 3.

[35] In most of the power plant boxes, the differences between model simulations using either the monthly default or real-time emission input were quite small, not more than $3 \times 10^{14}$ molecule $\mathrm{cm}^{-2}$. This small difference implies, for these plants at least, that the NEI99 default diurnal cycle in power plant $\mathrm{NO}_{\mathrm{x}}$ emissions is a reasonable approximation to the true diurnal cycle and that the day-to-day variability in $\mathrm{NO}_{\mathrm{x}}$ emissions is small. In the smaller FCSJ sampling 
Table 4. Geographic, Emissions, and Power Information of Power Plant Sampling Boxes ${ }^{\mathrm{a}}$

\begin{tabular}{|c|c|c|c|c|c|c|}
\hline Name (State) & $\begin{array}{c}\text { Center Lon. } \\
\text { (deg) }\end{array}$ & $\begin{array}{l}\text { Center Lat. } \\
(\mathrm{deg})\end{array}$ & $\begin{array}{l}\text { Width Lon. } \\
\text { (deg) }\end{array}$ & $\begin{array}{l}\text { Width Lat. } \\
\text { (deg) }\end{array}$ & $\begin{array}{c}\mathrm{NO}_{\mathrm{x}} \text { Emissions }^{\mathrm{b}} \\
(\mathrm{t})\end{array}$ & $\begin{array}{l}\text { Load }^{\mathrm{b}} \\
(\mathrm{MWh})\end{array}$ \\
\hline P1a: Four Corners/San Juan (N. M.), small & -108.50 & 36.75 & 1.00 & 0.500 & 26,724 & $13,046,122$ \\
\hline P1b: Four Corners/San Juan (N. M.), large & -108.46 & 36.75 & 2.00 & 1.000 & 26,724 & $13,046,122$ \\
\hline P2: Mohave (Nev.) & -114.59 & 35.15 & 1.00 & 0.788 & 8181 & $4,770,269$ \\
\hline P3: Reid Gardner (Nev.) & -114.64 & 36.65 & 0.75 & 0.375 & 3387 & $1,774,329$ \\
\hline P4: Navajo (Ariz.) & -111.39 & 36.91 & 1.00 & 0.788 & 13,464 & $8,326,453$ \\
\hline P5: Craig/Hayden (Colo.) & -107.39 & 40.48 & 1.00 & 0.788 & 9912 & $6,335,077$ \\
\hline P6: Dave Johnston/Laramie River (Wyo.) & -105.33 & 42.47 & 2.00 & 1.250 & 12,183 & $8,031,725$ \\
\hline P7: Hunter/Huntington (Utah) & -111.05 & 39.27 & 1.00 & 1.000 & 10,497 & $7,322,178$ \\
\hline P8: Intermountain (Utah) & -112.58 & 39.51 & 1.50 & 1.000 & 10,073 & $6,350,285$ \\
\hline P9: Cholla/Coronado/Springerville (Ariz.) & -109.58 & 34.61 & 2.50 & 1.000 & 13,833 & $9,239,411$ \\
\hline P10: Jim Bridger/Naughton (Wyo.) & -109.70 & 42.00 & 2.75 & 2.000 & 18,062 & $9,027,202$ \\
\hline P11: Bonanza (Utah) & -109.28 & 40.09 & 1.50 & 0.788 & 2845 & $1,688,207$ \\
\hline P12: Colstrip (Mont.) & -106.62 & 45.88 & 1.50 & 1.000 & 14,129 & $7,270,187$ \\
\hline P13: North Valmy (Nev.) & -117.15 & 40.88 & 2.00 & 1.000 & 3860 & $1,862,441$ \\
\hline
\end{tabular}

${ }^{\mathrm{a}}$ Lon., longitude; Lat., latitude.

${ }^{\mathrm{b}}$ Total $\mathrm{NO}_{\mathrm{x}}$ emissions (in metric tons) and gross load (electrical power output in megawatt-hours (MWh)) for the power plants in each box reported by CEMS during the 2005 summer ozone season (1 May to 30 September).

box (P1a), however, the model columns simulated with realtime emissions agree better with all satellite retrievals than those using monthly default emissions, with differences of as much as $7 \times 10^{14}$ molecule $\mathrm{cm}^{-2}$ between the simulations using the two different emission data sets. The NEI99 default diurnal cycle in power plant $\mathrm{NO}_{\mathrm{x}}$ emissions is much different from the nearly constant average hourly variability actually observed at FCSJ during the summer of 2005 (Figure 5). Use of default NEI99 diurnal factors for FCSJ can lead to $10-20 \%$ overestimates of $\mathrm{NO}_{\mathrm{x}}$ emissions at the overpass times of the satellites with the SCIAMACHY and OMI instruments, 1000 LST and 0130 LST, respectively. Figure 6 shows the daily emissions from Four Corners Power Plant, San Juan Power Plant, and the total of the two for the summer of 2005. Large reductions in total FCSJ emissions (up to $30 \%$ ) are seen periodically throughout the summer, particularly around weekends and the 4th of July holiday. Using monthly average emissions can bias the model predictions if the satellite data are taken on days that differ significantly from the monthly average. The real daily and hourly variability in FCSJ emissions both appear to contribute to biases seen in the model predictions of $\mathrm{NO}_{2}$ vertical column using the monthly default emissions input.

[36] Figure 7 shows the relationship between the model and the three satellite $\mathrm{NO}_{2}$ columns for the power plant boxes. Linear fits of the model results to the UB SCIAMACHY and NASA OMI data show that the model is $6-8 \%$ higher than the satellite on average with correlation coefficients, $r$, of $0.93-0.95$. A fit of the power plant model results to all UB OMI data shows that the model is $\sim 20 \%$ higher than the satellite data on average with a correlation coefficient, $r$, of 0.97 . Comparison of the model results to all three satellite data sets shows that the model is $\sim 10 \%$ higher than the satellite (not shown). These comparisons demonstrate the excellent agreement between the model $\mathrm{NO}_{2}$ columns and the satellite retrievals over regions dominated by power plant emissions. Previous comparisons of various satellite retrievals [Boersma et al., 2004; van Noije et al., 2006] showed much larger discrepancies than those seen here between the 3 satellite data sets in the power plant boxes.

\subsubsection{Sensitivity Studies for Four Corners-San Juan Boxes}

[37] Figures 8 and 9 show 14-day running averages of both satellite and model columns during the summer of 2005 in the two FCSJ power plant boxes (P1a in Figure 8 and $\mathrm{P} 1 \mathrm{~b}$ in Figure 9). The FCSJ boxes contain the largest CEMS $\mathrm{NO}_{\mathrm{x}}$ emissions and highest $\mathrm{NO}_{2}$ columns of the power plant areas considered here (Table 4). Figures 8 and 9 examine the variability in the model and satellite data due to changes in input assumptions and demonstrate the level of agreement between the model and satellite data throughout summer 2005.

\subsubsection{Sensitivity of Satellite Retrievals}

[38] The blue solid curves in Figure $8 \mathrm{a}$ and $8 \mathrm{~b}$ show the sensitivity of the two University of Bremen satellite $\mathrm{NO}_{2}$ column retrievals to different a priori model $\mathrm{NO}_{2}$ assumptions for the smaller FCSJ box (P1a). SCIAMACHY and OMI retrievals using the MOZART model $\mathrm{NO}_{2}$ profile give $\sim 10 \%$ higher values than those using the WRF-Chem model $\mathrm{NO}_{2}$ vertical profile shapes in June and July of 2005. Compared to WRF-Chem, MOZART has weaker vertical mixing and generally produces lower mixed layer heights, resulting in $\mathrm{NO}_{2}$ profiles with sharper vertical gradients near the surface (not shown). Furthermore, in WRF-Chem the emissions from elevated power plant stacks like those of FCSJ are injected as high as several hundred meters above the surface, while MOZART injects emissions from all surface sources into the lowest model vertical layer. Satellite sensitivity decreases toward the surface, so that higher $\mathrm{NO}_{2}$ near the surface in the MOZART profile leads to smaller AMFs and consequently higher vertical columns.

[39] Another minor difference between the two model $\mathrm{NO}_{2}$ profiles used in the UB retrievals is that the WRFChem profile is selected at the date and time appropriate for each satellite overpass, for example, 1000 LST or 0130 LST, while the MOZART model monthly mean profiles at 1000 LST were used for both instruments. A potential cause of model $\mathrm{NO}_{2}$ profile differences in situations of heterogeneous topography is the resolution of terrain heights, leading to different distributions of temperature near the surface and thus differences in the $\mathrm{NO}_{2}$ absorption cross 

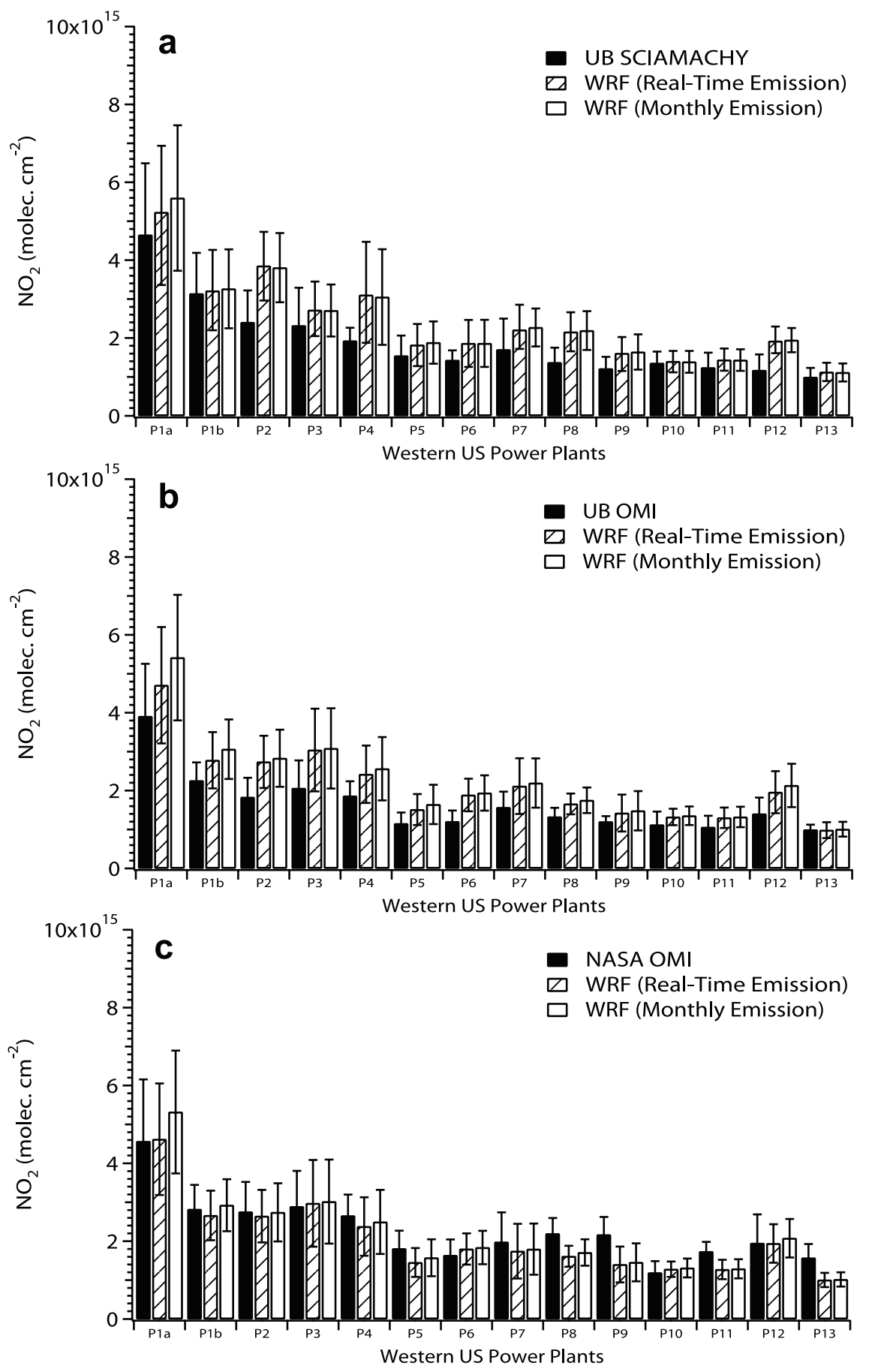

Figure 4. Comparison of summer 2005 average $\mathrm{NO}_{2}$ columns for power plant boxes (Table 4) from WRF-Chem with those from (a) UB SCIAMACHY, (b) UB OMI, and (c) NASA OMI. The solid bar, dashed bar, and open bar represent the satellite observations, the model with real-time emissions, and the model with monthly default emissions, respectively. The satellite data sets UB-SCIA 3a, UB-OMI 3a, and NASA-OMI 3 (Table 1) and model simulation cases M1 and M2 (Table 3) were used to construct this plot. Bars indicate 1 standard deviation in the summertime-mean box-average columns.

section. Schaub et al. [2007] have shown the importance of fine resolution terrain information on the $\mathrm{NO}_{2}$ satellite retrieval over the Alpine region in Switzerland. A Heckel et al. (Influence of under-sampling in a priori data on tropospheric $\mathrm{NO}_{2}$ satellite retrievals, manuscript in preparation, 2009) discuss in more detail the effects of the resolution of the model input data on the UB satellite retrievals. There are not significant differences in terrain heights between MOZART and WRF-Chem models for the FCSJ region, so we do not believe this effect plays an important role here. 


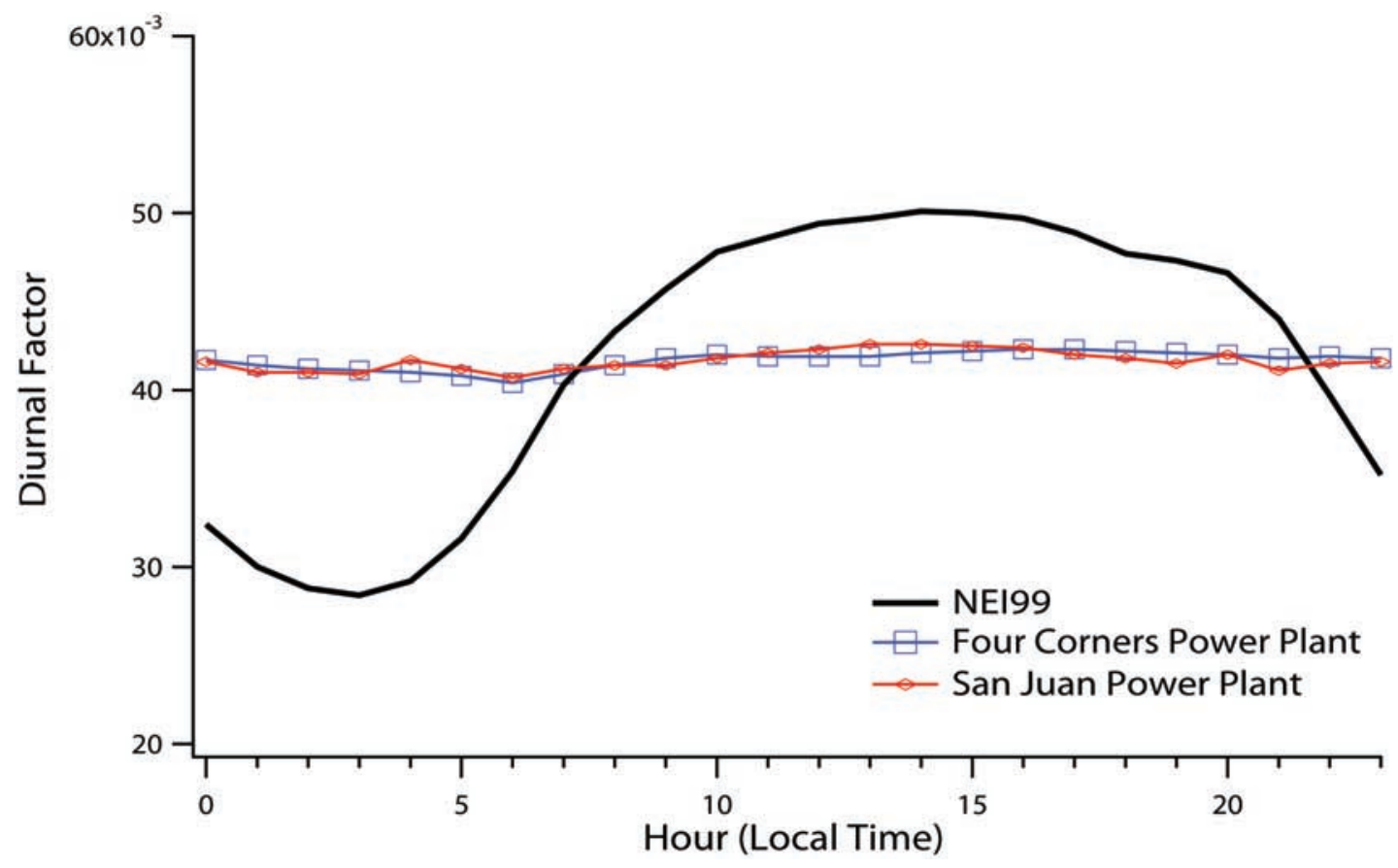

Figure 5. Diurnal factors distributing the daily total $\mathrm{NO}_{\mathrm{x}}$ emissions to hourly emissions. The black solid line denotes the default factors used in the 1999 EPA National Emission Inventory. The blue solid line with open squares (red solid line with diamond) denotes the actual diurnal factors determined from summer 2005 average CEMS data at the Four Corners (San Juan) Power Plant.

[40] Aerosols do not significantly affect the UB-retrieved $\mathrm{NO}_{2}$ columns from either satellite over the Four Corners region, within the range of aerosol loadings used. It should be noted that the assumed "rural" aerosol type used for the regions around all power plant boxes in this study was mostly scattering aerosol with little absorption. Thus aerosol is not expected to have a large impact on the calculated

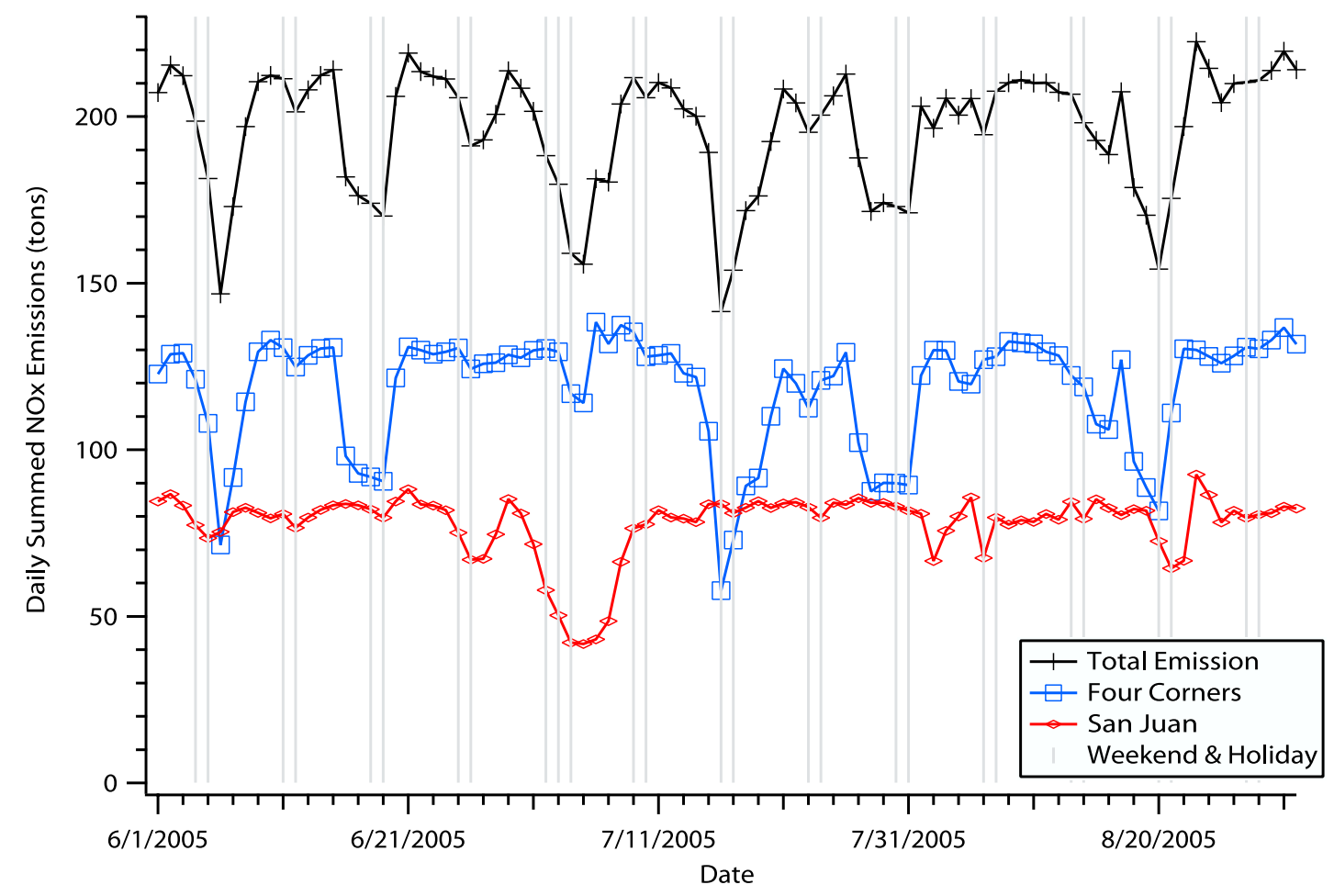

Figure 6. Daily CEMS $\mathrm{NO}_{\mathrm{x}}$ emissions from the Four Corners Power Plant (squares), San Juan Power Plant (diamonds), and the total from both plants (crosses) during the summer of 2005. Gray vertical lines indicate weekend days and holidays. 

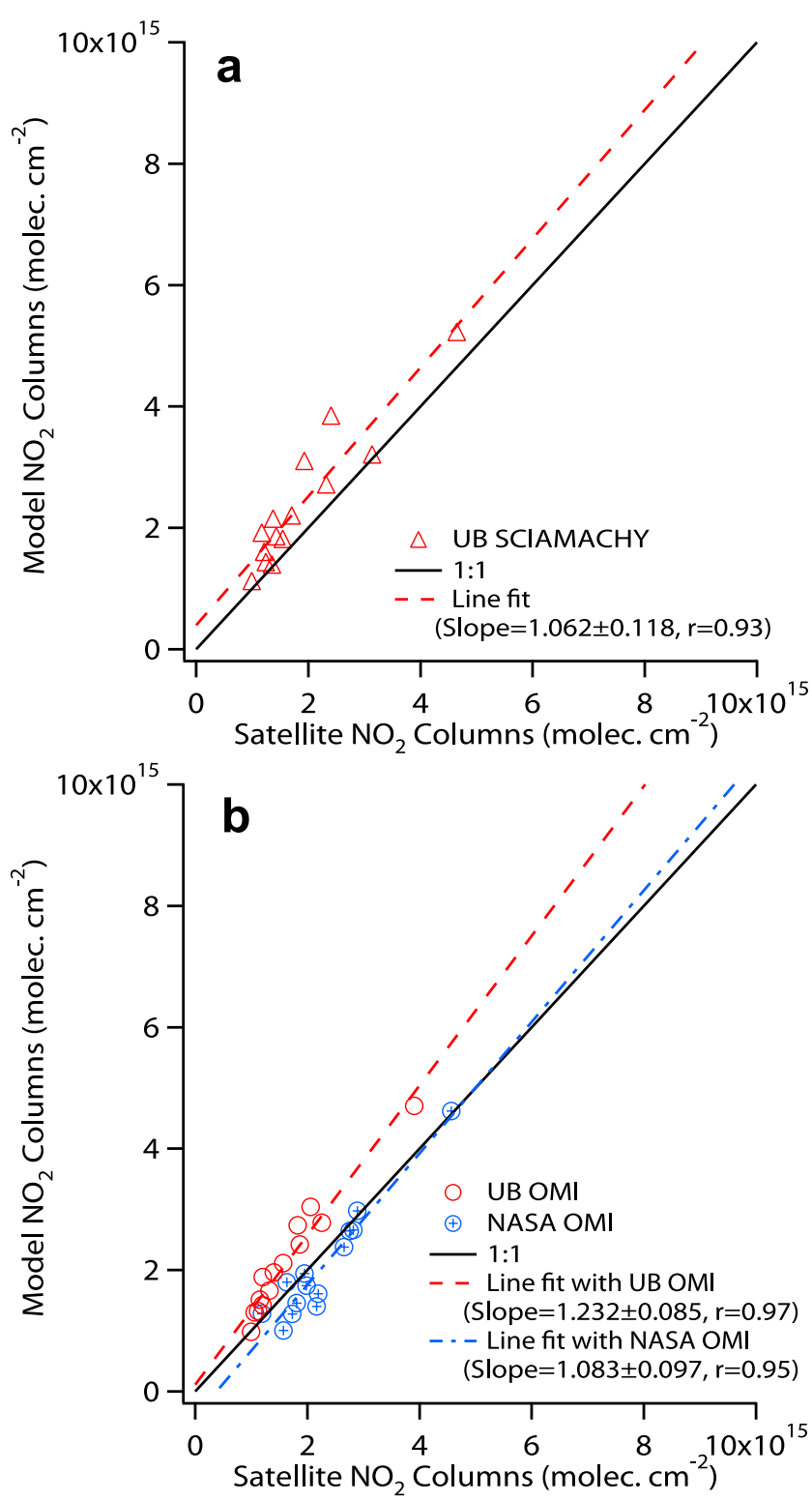

Figure 7. Scatterplot of model and satellite average summer $2005 \mathrm{NO}_{2}$ columns for each of the power plant boxes listed in Table 4 . Triangles, open circles, and circles with crosses denote data from (a) UB SCIAMACHY and (b) UB OMI and NASA OMI, respectively. The one-to-one line (black solid line) is also shown. The linear fit results given by the red dashed and blue dash-dotted lines are for the UB data sets and the NASA data, respectively. Data in these plots are the same as in Figure 4.
AMF over most of western U.S. power plants, which tend to be located far from urban areas.

[41] Figure 8d shows the number of satellite pixels used to construct the 14-day running mean. Less than 10 SCIAMACHY pixels are used for these averages. The number of OMI pixels used is up to 10 times as many as those of SCIAMACHY. The number of pixels for UB OMI is very similar to those for NASA OMI, although the two OMI data sets are not identical owing to minor differences in the definition of pixel corner points and quality assurance criterion in the two OMI data sets.

[42] To illustrate the sensitivity of the analysis to the size of the sampling box, Figure 9 shows the same results as Figure 8 except for the larger FCSJ box (P1b). The number of samples (Figure 9d) collected in the larger FCSJ box (P1b) is 4 times larger than for the smaller FCSJ box (P1a). The absolute column values and the spread between the resulting columns is less in $\mathrm{P} 1 \mathrm{~b}$ than $\mathrm{P} 1 \mathrm{a}$, as would be expected when averaging the satellite signal from an isolated point source over a larger area. However, the sensitivities of the UB satellite retrievals to $\mathrm{NO}_{2}$ profile and aerosols in box P1b are similar to those seen in P1a. So the effect of using different input parameters in the retrieval does not depend on the size of the averaging box.

\subsubsection{Sensitivity in WRF-Chem Simulations}

[43] Figures 8 and 9 also show the sensitivity of model $\mathrm{NO}_{2}$ columns to chemical mechanism and advection scheme over the P1a and P1b power plant boxes, respectively. At the time of the SCIAMACHY overpass, the model is more sensitive to the advection scheme than to the choice of chemical mechanism (compare the three red curves in Figures $8 \mathrm{a}$ and 9a). The positive-definite (PD) advection scheme reduces the simulated $\mathrm{NO}_{2}$ columns by $\sim 10 \%$ compared to those without this scheme. Model sensitivity to the chemical mechanisms is much higher at the time of the OMI overpass than during the SCIA overpass (compare Figures $8 \mathrm{~b}$ and $8 \mathrm{c}$ to Figure $8 \mathrm{a}$, and similarly for Figure 9), implying a more important role of photochemistry in determining afternoon $\mathrm{NO}_{2}$ levels.

[44] WRF-Chem $\mathrm{NO}_{2}$ columns over FCSJ also respond to changes in how the hourly and daily fluctuations in the power plant emissions are treated. As noted above for the summer 2005 averages, the 14-day running average model columns using the more accurate real-time emissions are generally lower than those using default monthly emissions (Figures 8 and 9), because the default temporal factors tend to exaggerate diurnal variability at these particular power plants. For the smaller box (P1a), differences between the modeled columns using the default monthly emissions and the real-time emissions (black curves in Figures $8 \mathrm{a}-8 \mathrm{c}$ )

Figure 8. Comparison of 14-day running mean model $\mathrm{NO}_{2}$ columns averaged over the smaller FCSJ box (P1a) with (a) UB SCIAMACHY, (b) UB OMI, and (c) NASA OMI, and (d) the number of satellite pixels included in each 14-day mean. In Figures $8 \mathrm{a}-8 \mathrm{c}$, the red solid line with solid triangles (open triangles) denotes the model results with the RACM-ESRL (RADM2) chemical mechanism with the positive-definite advection scheme. The model results with the nonpositivedefinite scheme and RACM-ESRL chemical mechanism are shown by the red dashed line with solid triangles. The model result using the positive-definite scheme, RACM-ESRL, and real-time emissions are represented by the black line. The blue solid line with solid circles (open circles) denotes UB satellite products retrieved with a priori $\mathrm{NO}_{2}$ profile from MOZART (WRF-Chem). UB products retrieved with no aerosols are plotted as blue dashed lines with open circles. In Figure 8d, open triangles and open circles represent UB SCIAMACHY and OMI data, respectively, and solid circles denote NASA OMI data. Satellite data sets UB-SCIA 3a-c, UB-OMI 3a-c, and NASA-OMI 3 (Table 1) and model simulation cases M1-M4 (Table 3) are plotted. 

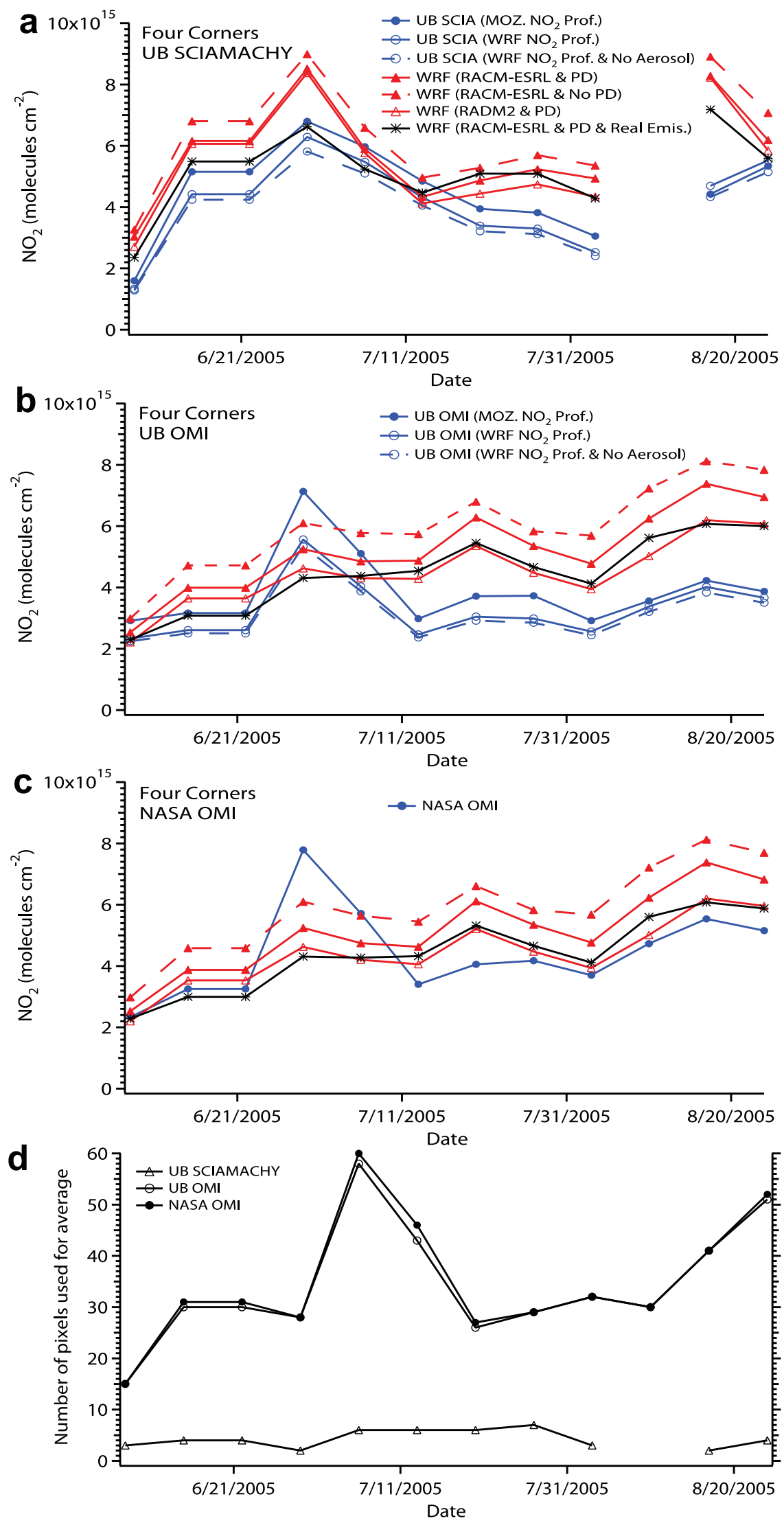

Figure 8

13 of 29 

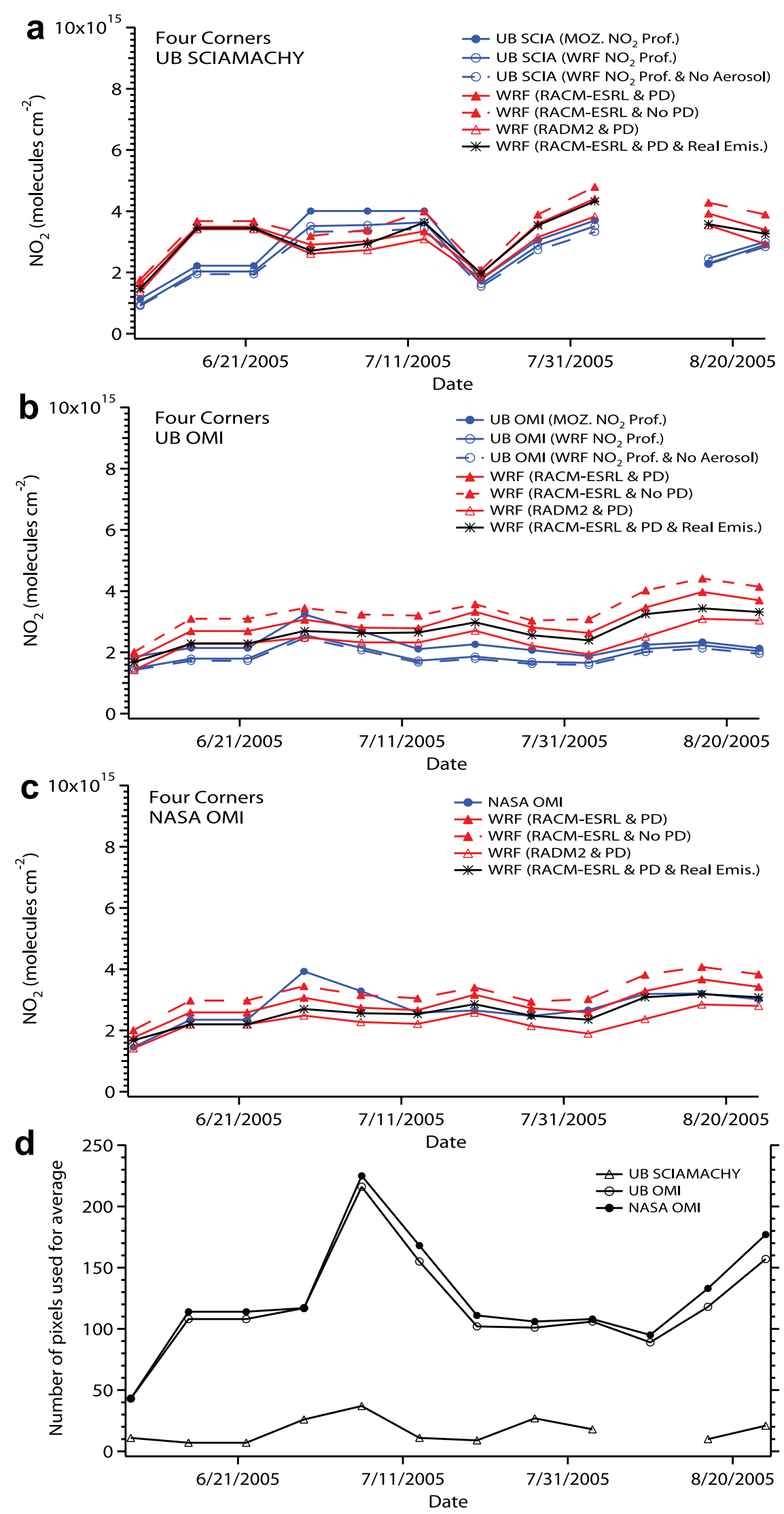

Figure 9. The same as in Figure 8 except for the larger FCSJ sampling box (P1b). 
Table 5. Geographic Information of City Sampling Boxes ${ }^{\mathrm{a}}$

\begin{tabular}{lcccc}
\hline & $\begin{array}{c}\text { Center } \\
\text { Lon. } \\
\text { (deg) }\end{array}$ & $\begin{array}{c}\text { Center } \\
\text { Lat. } \\
\text { (deg) }\end{array}$ & $\begin{array}{c}\text { Width } \\
\text { Lon. } \\
\text { (deg) }\end{array}$ & $\begin{array}{c}\text { Width } \\
\text { Lat. } \\
\text { (deg) }\end{array}$ \\
\hline C1: Los Angeles (Calif.) & -118.25 & 34.05 & 3.50 & 2.000 \\
C2: San Francisco (Calif.) & -122.42 & 37.70 & 1.50 & 1.000 \\
C3: Sacramento (Calif.) & -121.50 & 38.58 & 1.00 & 0.750 \\
C4: Fresno (Calif.) & -119.75 & 36.75 & 1.50 & 0.750 \\
C5: Bakersfield (Calif.) & -119.02 & 35.37 & 2.00 & 0.625 \\
C6: Las Vegas (Nev.) & -115.20 & 36.17 & 1.50 & 0.625 \\
C7: Reno (Nev.) & -119.65 & 39.50 & 1.00 & 1.000 \\
C8: Salt Lake City (Utah) & -111.88 & 40.77 & 1.00 & 1.000 \\
C9: Denver (Colo.) & -105.00 & 39.75 & 2.00 & 1.250 \\
C10: Phoenix (Ariz.) & -112.08 & 33.45 & 1.75 & 1.000 \\
C11: Tucson (Ariz.) & -110.92 & 32.22 & 1.00 & 0.750 \\
C12: E1 Paso (Tex.) & -106.48 & 31.75 & 1.50 & 1.000 \\
C13: Albuquerque (N. M.) & -106.38 & 35.38 & 1.25 & 1.250 \\
C14: Boise (Idaho) & -116.00 & 43.40 & 1.00 & 1.000 \\
\hline
\end{tabular}

${ }^{\mathrm{a}}$ Lon., longitude; Lat., latitude.

throughout the summer of 2005 were as much as $2 \times 10^{15}$ molecule $\mathrm{cm}^{-2}$ at 1000 LST (Figure 8a) and $1.5 \times 10^{15}$ molecule $\mathrm{cm}^{-2}$ at 0130 LST (Figures $8 \mathrm{~b}-8 \mathrm{c}$ ). The impact of real-time emissions is lower for the larger box, P1b (Figure 9).

\subsubsection{Comparison of Satellite and Model}

[45] The spread in results using different input data in the retrieval of the satellite columns and the calculation of model columns provides one measure of the systematic uncertainties involved. In general, there is a wider range in the model columns calculated under different assumptions than there is for the UB satellite columns retrieved with different inputs. Model $\mathrm{NO}_{2}$ columns with monthly default emissions in the P1a box (the red curves in Figure 8) are almost always higher than any of the SCIAMACHY or OMI columns retrieved under various assumptions (the blue curves in Figure 8). The model $\mathrm{NO}_{2}$ columns calculated with real-time emissions and RACM-ESRL chemical mechanism agree best with the SCIAMACHY and OMI data early in the summer, but the real-time emissions do not always give the best agreement later in the summer. The model is generally closer to the NASA OMI results (Figure 8c) than the UB columns throughout most of the summer.

[46] The model results in the larger FCSJ box, P1b, (Figure 9) are usually in closer agreement with the satellite data than in the smaller FCSJ box, P1a (Figure 8). The larger satellite-model discrepancies over Pla can be attributed to possible errors in model plume dispersion, which in turn depends on predicted wind speed, wind direction, and turbulence. The real-time CEMS emissions somewhat improve the model predictions in the larger box but their impact is relatively minor. The overall agreement between the model (with real-time emissions) and any of the three satellite retrievals in the larger FCSJ box (P1b) during any 14-day period of summer 2005 is within $1.5 \times 10^{15}$ molecule $\mathrm{cm}^{-2}$.

\section{3. $\mathrm{NO}_{2}$ Columns Over Urban Areas}

[47] Plumes from cities are the dominant signals in the satellite $\mathrm{NO}_{2}$ column distribution in the western United States (Figures 2 and 3). Using a procedure similar to the power plants, boxes were defined to encompass most of the $\mathrm{NO}_{2}$ plumes from 14 western U.S. urban areas (Figure 2 and Table 5). Using the good agreement between the model and satellite-retrieved $\mathrm{NO}_{2}$ columns over power plants as a starting point, comparisons of these data sets over western U.S. cities are used to evaluate urban $\mathrm{NO}_{\mathrm{x}}$ emissions.

\subsubsection{Weekly Cycles}

[48] Both inventories and in situ observations suggest that $\mathrm{NO}_{\mathrm{x}}$ emissions in urban areas are dominated by mobile sources. One indicator of the predominance of mobile sources is the existence of a clear weekly cycle in urban $\mathrm{NO}_{\mathrm{x}}$ levels. Roadside monitoring data [Harley et al., 2005] demonstrate such a cycle, with reductions in on-road $\mathrm{NO}_{\mathrm{x}}$ emissions of $27 \%(43 \%)$ on weekends relative to weekdays in 1990 (2000) in California. Satellite $\mathrm{NO}_{2}$ signals have also been used to derive weekly cycles in urban regions around the world [Beirle et al., 2003]. As an example, using the data sets presented here, we examined the day-of-week variations of $\mathrm{NO}_{2}$ columns over Los Angeles, California (Figure 10). The huge reduction in $\mathrm{NO}_{2}$ columns on Sundays can clearly be seen in NASA OMI images over Los Angeles (see Figure 10, middle column).

[49] Figure 11 shows the weekly cycles derived from multiyear averages of summer ozone season (May to September) daily satellite $\mathrm{NO}_{2}$ columns, including 2003 to 2007 for SCIAMACHY and 2005 to 2007 for OMI. Figures $11 \mathrm{a}$ and $11 \mathrm{~b}$ show absolute $\mathrm{NO}_{2}$ columns averaged over the box area, while Figures $11 \mathrm{c}$ and $11 \mathrm{~d}$ show the columns normalized to their Thursday values. We focus on ozone season satellite data to avoid the larger variability and larger plume spreading seen in winter [van Noije et al., 2006].

[50] Both satellite data sets (Figure 11) indicate $\mathrm{NO}_{2}$ columns in Los Angeles, San Francisco (California), Sacramento (California), Las Vegas (Nevada), and Phoenix (Arizona) have clear weekly cycles, with weekend $\mathrm{NO}_{2}$ columns reduced by $30-60 \%$ compared to their Thursday levels. Other western U.S. cities under investigation also demonstrate weekly cycles to some degree. The amplitudes of the weekly cycles in Fresno (California) and Bakersfield (California) are smaller than those in other large cities in California, suggesting that agricultural $\mathrm{NO}_{\mathrm{x}}$ emissions as well as different day-of-week traffic patterns may play a role in reducing weekly variations of $\mathrm{NO}_{\mathrm{x}}$ emissions in these cities. In contrast, $\mathrm{NO}_{2}$ columns averaged over Nebraska do not show significant weekly variations (Figure 11) owing to the predominantly rural character of this state compared with California, Nevada, and Arizona.

[51] Comparing SCIAMACHY and OMI weekly cycles, the variability is smaller in OMI data for all locations. This is consistent with the larger relative contribution of mobile sources in the weekday morning rush hour than around noon when the OMI measurements are taken. The increased contribution of photochemistry to afternoon $\mathrm{NO}_{2}$ levels might also lead to smaller day-of-week cycles in OMI columns.

[52] It is obvious that the incorporation of this weekly cycle into the inventory is necessary for the accurate simulation of $\mathrm{NO}_{2}$. In further analysis of the satellite observations over urban areas, weekend days are excluded because day-of-week variability in the emission inventory is not included in the present model simulations.

3.3.2. Comparison of Summer 2005 Average Columns

[53] Figure 12 shows summer 2005 average $\mathrm{NO}_{2}$ columns from the satellites and the model over the urban area boxes. Compared with the analogous picture for power 

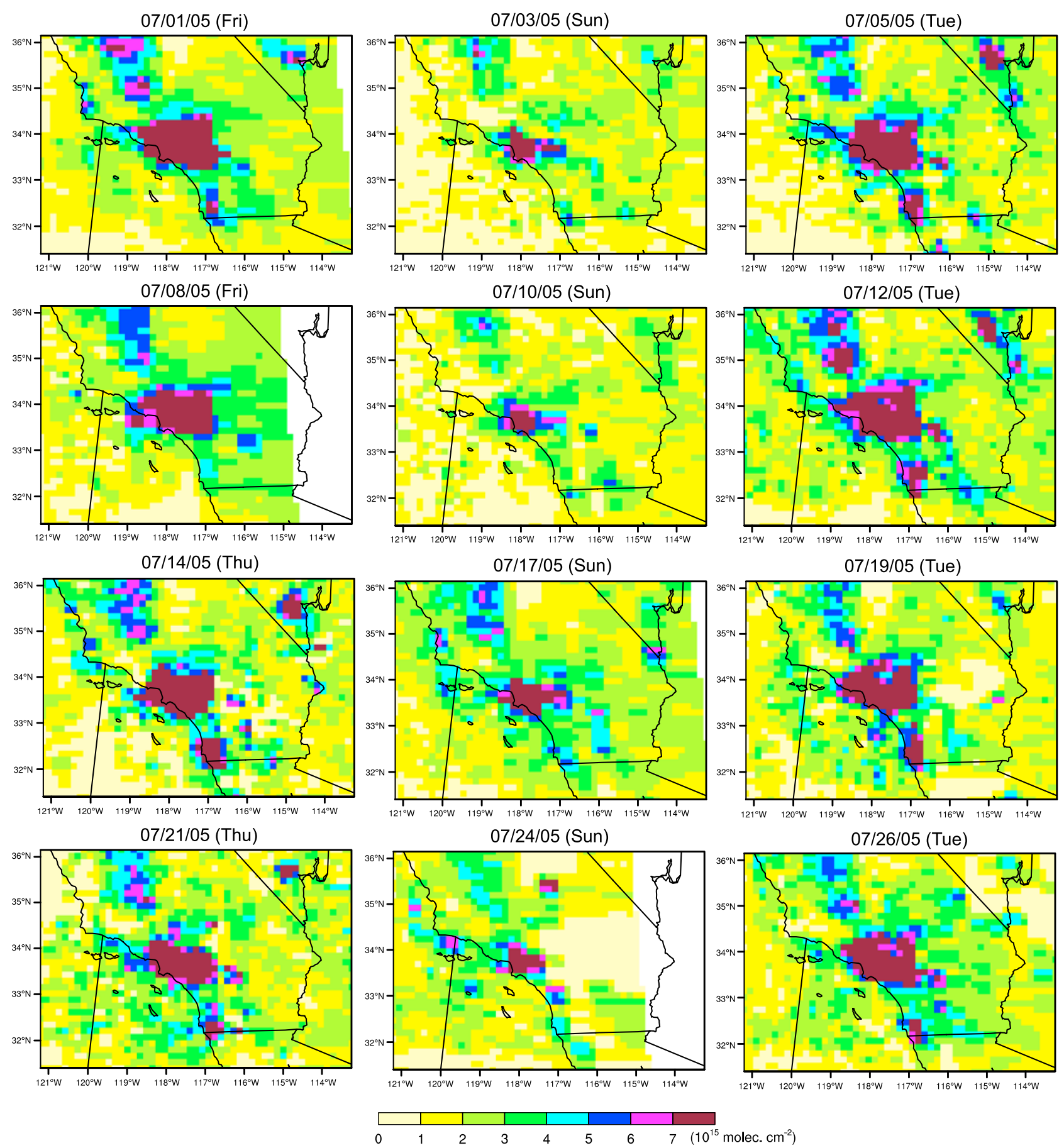

Figure 10. Snapshots of $\mathrm{NO}_{2}$ columns over Los Angeles, California, observed by NASA OMI during July of 2005.

plants (Figure 4), there are discrepancies between the model and the satellite columns over some western U.S. cities that are larger than the variability in the satellite and model data (see below). The model $\mathrm{NO}_{2}$ columns are as much as a factor of two larger than those from the satellites over the California cities of Los Angeles, San Francisco, Sacramento, Fresno, and Bakersfield. The model results are also consistently higher than the satellite observations in Salt Lake City (Utah) and Phoenix. In contrast, two of the three satellite products show higher $\mathrm{NO}_{2}$ columns than the model over Las Vegas. Discrepancies between model and the various satellite columns are smaller over Reno (Nevada), Denver (Colorado), Tucson (Arizona), El Paso (Texas), Albuquerque (New Mexico), and Boise (Idaho).

[54] Figure 13 shows the relationship between the model and the satellite columns for the urban sampling boxes. A linear fit of the model results to all urban UB SCIAMACHY data shows that the model is $\sim 60 \%$ higher than the satellite on average with a correlation coefficient, $r$, of 0.87 . Linear fits of the model to the urban OMI data indicate that the 


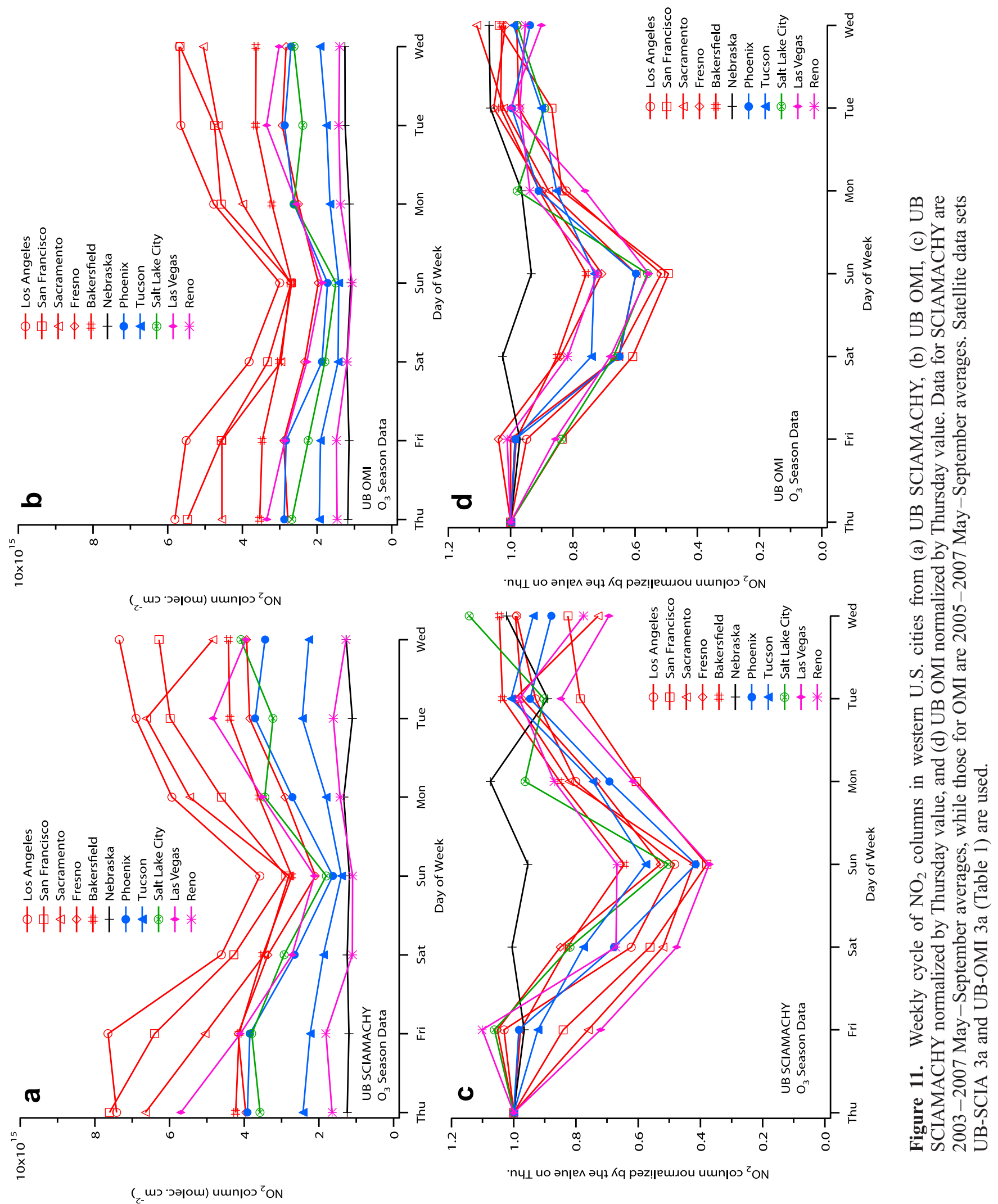



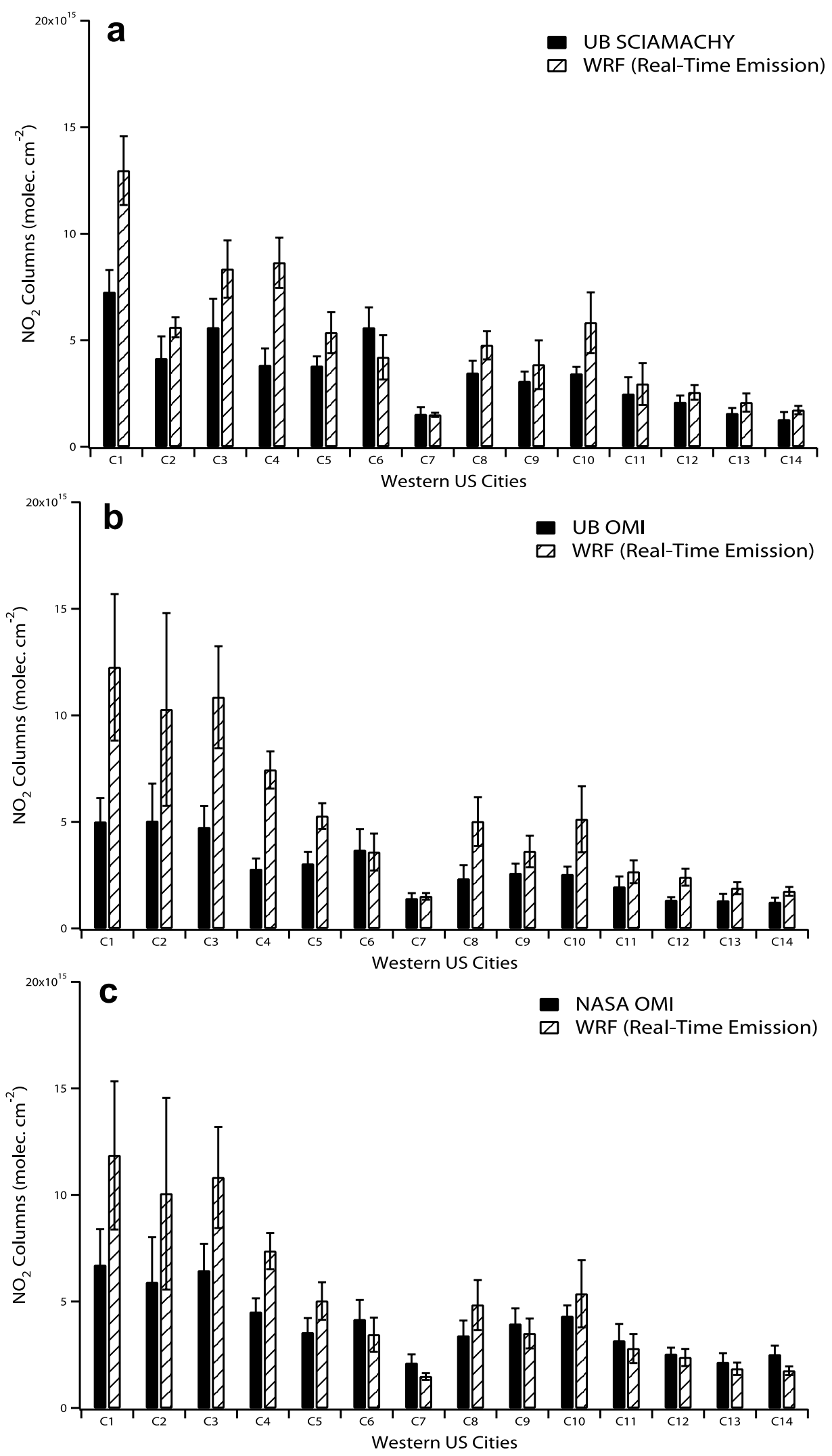

Figure 12. Comparison of the summer 2005 average $\mathrm{NO}_{2}$ columns for city boxes from WRF-Chem with those from (a) UB SCIAMACHY, (b) UB OMI, and (c) NASA OMI. The solid and dashed bars represent the satellite observations and model with real-time emissions, respectively. The satellite data sets UB-SCIA 3a, UB-OMI 3a, and NASA-OMI 3 (Table 1) and model simulation case M2 (Table 3) were used to construct these plots. Bars indicate 1 standard deviation in the summertime-mean boxaverage columns. Note that the vertical axis scale in these plots differs from that of Figure 4. 

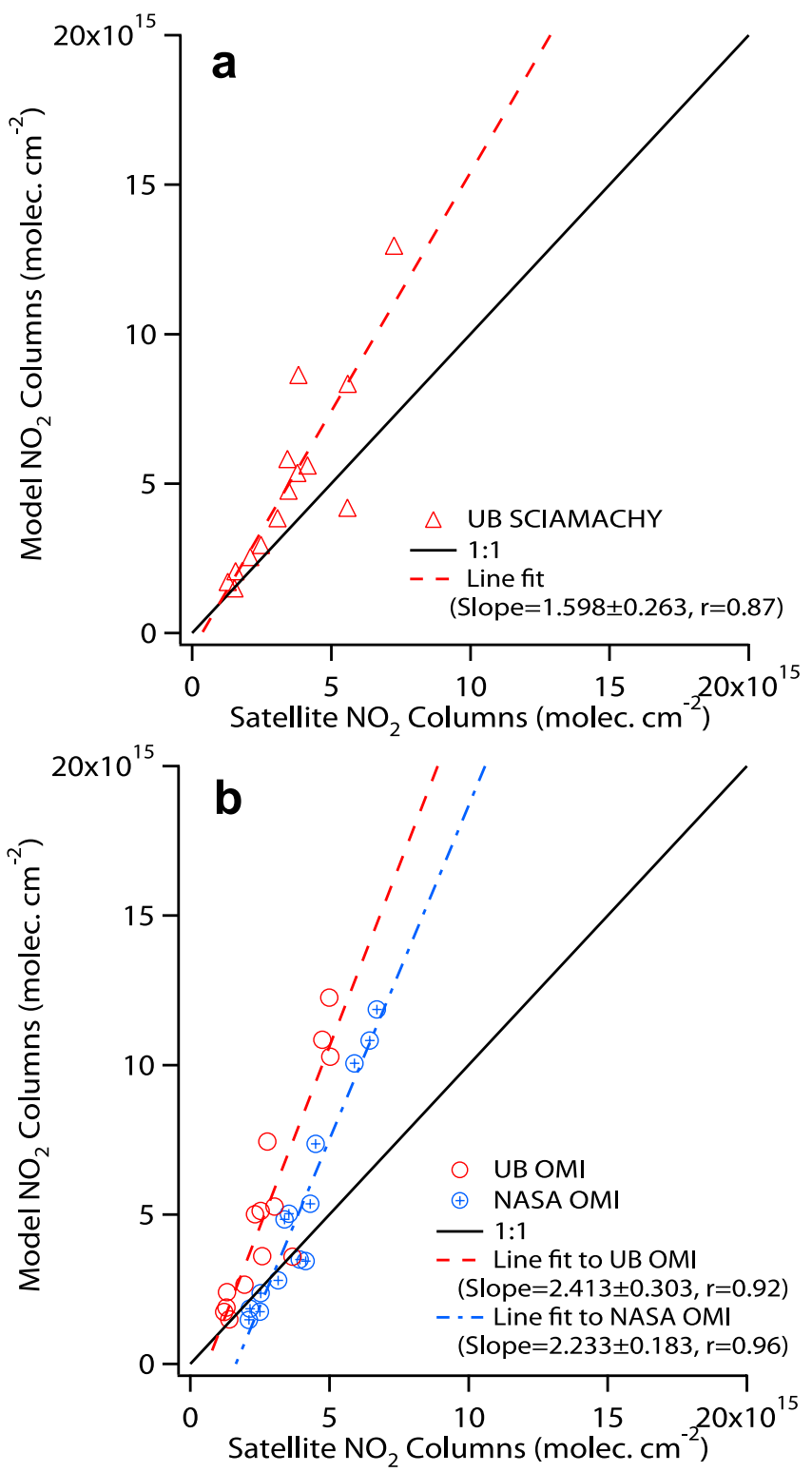

Figure 13. Similar to Figure 7, except for the summer 2005 city box-average $\mathrm{NO}_{2}$ columns. The vertical and horizontal axis scales also differ from Figure 7. The data shown here are the same as those in Figure 12.

model is $120-140 \%$ higher than the satellite on average with $r$ of $0.92-0.96$.

\subsubsection{Sensitivity Studies for the Los Angeles Box}

[55] Figure 14 shows the sensitivity of the satellite and the model $\mathrm{NO}_{2}$ columns to various input parameters for the Los Angeles sampling box. Similar to the sensitivity studies in the Four Corners-San Juan sampling boxes (Figures 8 and 9), 14-day running averages of UB SCIAMACHY and OMI columns retrieved with different $\mathrm{NO}_{2}$ and aerosol profiles are compared to WRF-Chem columns calculated with different mechanisms and advection schemes for the Los Angeles box over the summer 2005. The number of satellite pixels used in each 14-day average are shown in Figure 14d.

\subsubsection{Sensitivity of Satellite Retrievals}

[56] In contrast to the FCSJ sampling boxes, SCIAMACHY retrieved over Los Angeles using the WRF-Chem $\mathrm{NO}_{2}$ vertical profile gives up to $10 \%$ higher columns than those retrieved using the MOZART model $\mathrm{NO}_{2}$ profile (Figure 14a). There is little effect of changing the $\mathrm{NO}_{2}$ profile on the UB OMI results (Figure 14b). Horizontal distributions of differences between the satellite $\mathrm{NO}_{2}$ columns retrievals using the WRF-Chem and MOZART model profiles show that $\mathrm{NO}_{2}$ columns from the retrieval using WRF-Chem model are much higher at the urban core of the Los Angeles basin and are lower in the surrounding mountainous area than those based on the MOZART model (not shown). Unlike the FCSJ box, the dominant effect leading to different model AMFs over Los Angeles is the resolution of terrain height [Schaub et al., 2007]. The steep topography surrounding Los Angeles is resolved differently by MOZART and WRF-Chem, causing model-model differences in nearsurface temperatures which lead to positive or negative deviations of satellite $\mathrm{NO}_{2}$ columns using WRF-Chem profiles from those using MOZART profiles. When averaged over the Los Angeles sampling box results, these positive and negative deviations largely cancel each other, making the impact of WRF-Chem $\mathrm{NO}_{2}$ profiles on the box-averaged columns rather small.

[57] As expected, changing the assumed aerosol distribution has a substantial effect on the UB SCIAMACHY and OMI retrievals in Los Angeles. The retrieval without aerosol reduces the column by $\sim 30 \%$ (compare the blue dashed line with open circles to the blue solid line with open circles in Figures 14a and 14b). The assumed aerosol over urban areas is highly absorbing, since urban aerosols presumably should contain significant amounts of black carbon. The presence of highly absorbing aerosols leads to a lower AMF and a higher vertical column of $\mathrm{NO}_{2}$. The effect of aerosols on the retrievals over Los Angeles can be compared with that over FCSJ (Figures 8 and 9), where aerosols are assumed to be mostly scattering with little absorption, consequently having only a small impact on the AMF.

\subsubsection{Sensitivity in WRF-Chem Simulations}

[58] The simulated $\mathrm{NO}_{2}$ columns over Los Angeles are sensitive to both the advection schemes and the chemical mechanisms (red curves in Figure 14). As was the case over FCSJ, the positive-definite advection scheme reduces the simulated $\mathrm{NO}_{2}$ columns by $\sim 10 \%$ compared to those calculated without this scheme, for both satellite overpass times. $\mathrm{NO}_{2}$ columns simulated by the RADM2 mechanism over Los Angeles are $\sim 10 \%$ and $\sim 20 \%$ lower than those by RACM-ESRL mechanism at the time of the SCIAMACHY and OMI overpass times, respectively. The larger effect in the afternoon is similar to the result over FCSJ. The magnitude of the chemical mechanism effect in both the morning and afternoon is larger over Los Angeles than FCSJ, suggesting differences in the chemical composition of the urban atmosphere and the rural power plant plume.

\subsubsection{Comparison of Satellite and Model}

[59] The overall range of $\mathrm{NO}_{2}$ columns seen for the various satellite and model sensitivity studies over Los Angeles (Figure 14) is wider than that seen in columns over FCSJ (Figures 8 and 9). However, the discrepancy between all three satellite retrievals and their corresponding model simulations over Los Angeles is much larger than 

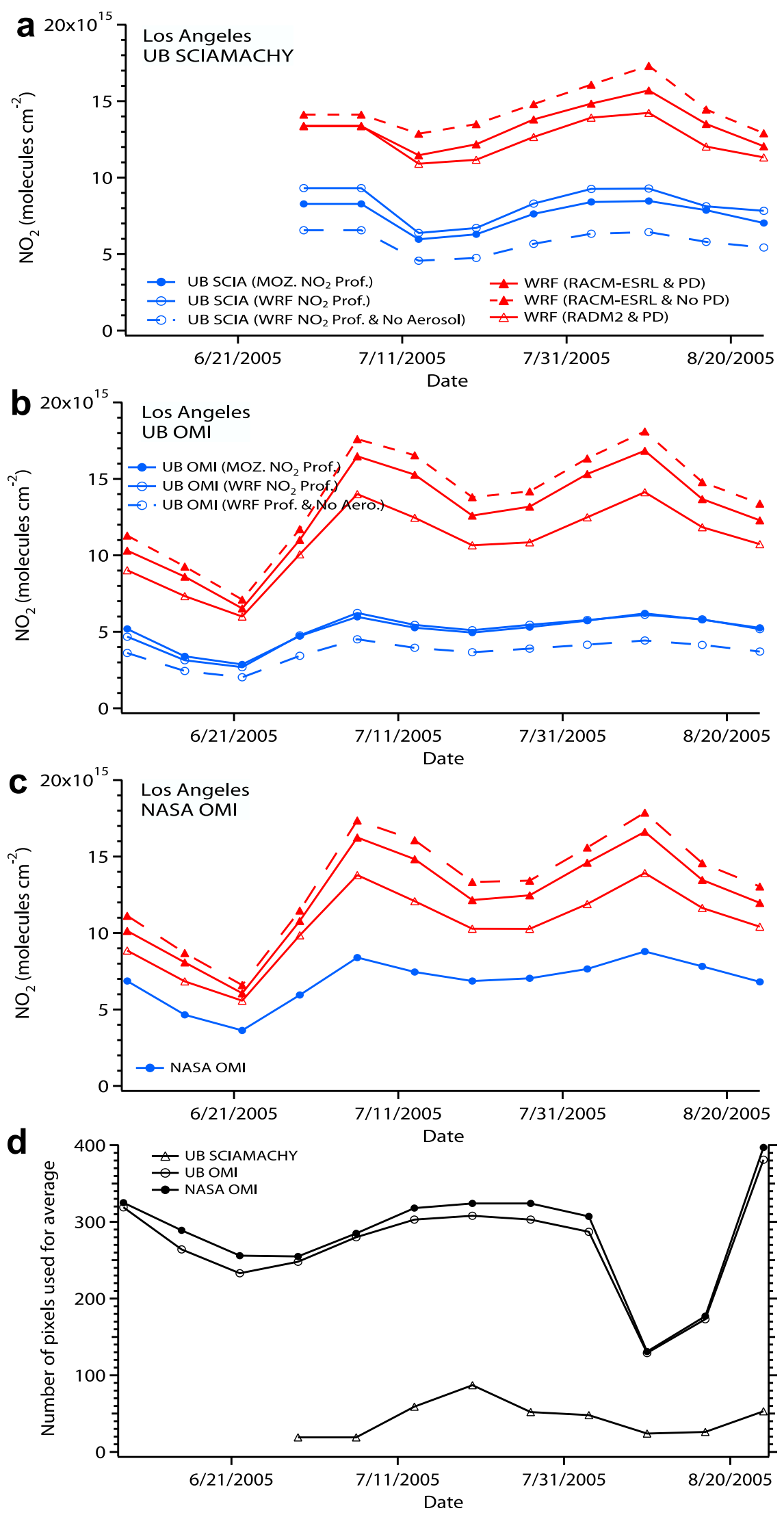

Figure 14. Similar to Figure 8 except for the Los Angeles sampling box. Vertical scale is different here than in Figure 8. 


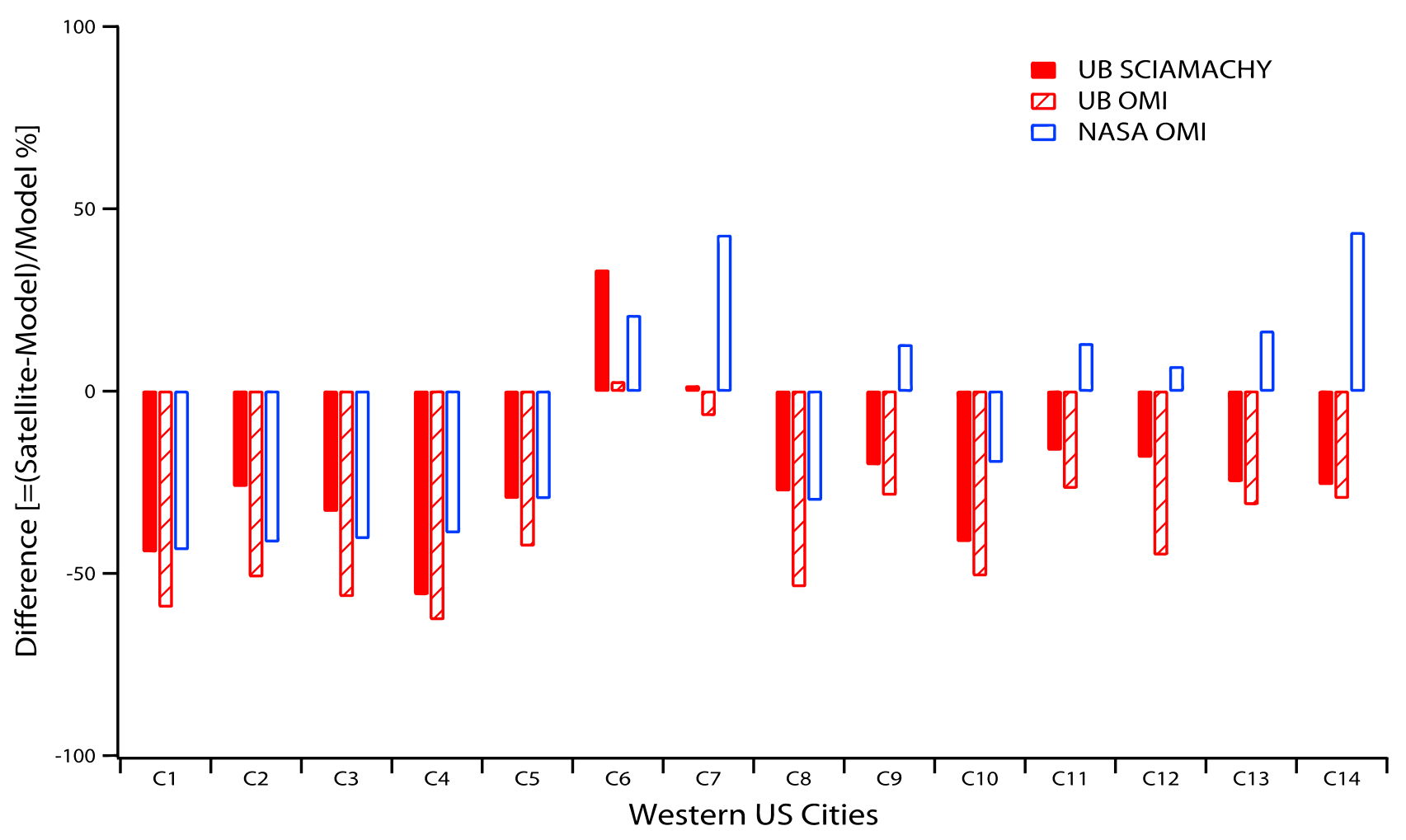

Figure 15. Differences between model and satellite $\mathrm{NO}_{2}$ columns over western U.S. cities, defined as $100 \times\left(\right.$ satellite $\mathrm{NO}_{2}$ column - model $\mathrm{NO}_{2}$ column $) /$ model $\mathrm{NO}_{2}$ column. Solid, hatched, and open bars represent UB SCIAMACHY, UB OMI, and NASA OMI, respectively. Data in Figure 12 are used.

that seen over FCSJ. In all cases, the Los Angeles model columns are larger than the satellite columns by approximately a factor of 2 or more. The possible systematic errors in the model and satellite retrieval input assumptions discussed above do not appear to be large enough to cause this model-satellite discrepancy. Instead, the most likely explanation of this large model bias is that the $\mathrm{NO}_{\mathrm{x}}$ emissions in Los Angeles and other western U.S. urban areas are substantially different from the NEI99 inventory used here. This possibility is explored in detail in section 3.4.

\subsection{Satellite $\mathrm{NO}_{2}$ Column Trends and Inventory Trends and Biases}

[60] The relative differences between the summer 2005 model and satellite $\mathrm{NO}_{2}$ columns (defined as $100 \times$ (satellite $\mathrm{NO}_{2}$ column - model $\mathrm{NO}_{2}$ column)/model $\mathrm{NO}_{2}$ column) in the western U.S. city sampling boxes are shown in Figure 15. One simple explanation for the large $\mathrm{NO}_{2}$ column differences over the majority of these cities is that urban $\mathrm{NO}_{\mathrm{x}}$ emissions changed between 1999 (represented by the NEI99 model inventory) and 2005 (the year that the satellite data were collected). On the other hand, if the NEI99 inventory does not adequately represent $1999 \mathrm{NO}_{\mathrm{x}}$ emissions in these cities, then a 1999-2005 trend in $\mathrm{NO}_{\mathrm{x}}$ emissions cannot be inferred from the model-satellite discrepancies over these cities. These possibilities are examined in more detail in sections 3.4.1-3.4.3.

\subsubsection{Satellite $\mathrm{NO}_{2}$ Column Trend Analysis}

[61] We investigated year-to-year trends in satellite $\mathrm{NO}_{2}$ columns to infer trends in $\mathrm{NO}_{\mathrm{x}}$ emissions over urban areas, the Four Corners-San Juan sampling box, and several western U.S. states. Here trends are defined as short-term statistically significant linear changes, although emission changes may also be nonlinear. SCIAMACHY data are available from 2003 to 2007 and OMI data cover 20052007. The satellite data used in the year-to-year trend analyses explored in this section are May-September averages of the monthly mean gridded data for each of the above years. The May-September period was chosen to correspond to the summer ozone season used in the emission estimates discussed below. The 2005 ozone season average $\mathrm{NO}_{2}$ columns from each of the three satellite retrievals used in the trend analyses below (from data sets UB-SCIA 1, UB-OMI 1, and NASA-OMI 1) quantitatively differ from those used in the 2005 satellite-model comparisons discussed earlier in section 3. Differences in these data sets include the period studied (i.e., May-September versus June-August), the spatial averaging (orbital swath versus regular grid), and cloud screening (a less stringent cloud fraction threshold is used in the monthly mean data). However, the most important criterion for each satellite data set is that it is averaged the same way in each year, since the year-to-year trend is being examined here.

[62] Prior to 2003, there were satellite observations of $\mathrm{NO}_{2}$ columns by the GOME instrument which have been used to study large-scale emission changes in the eastern U.S. [Kim et al., 2006]. However, the resolution of GOME $(340 \mathrm{~km}$ across-track direction $\times 60 \mathrm{~km}$ along-track direction) is too coarse to isolate individual western U.S sources using the sampling boxes defined in this study. GOME data were therefore not considered in this study.

[63] Figure 16 shows the recent changes in ozone season (May-September) average $\mathrm{NO}_{2}$ columns from the monthly 

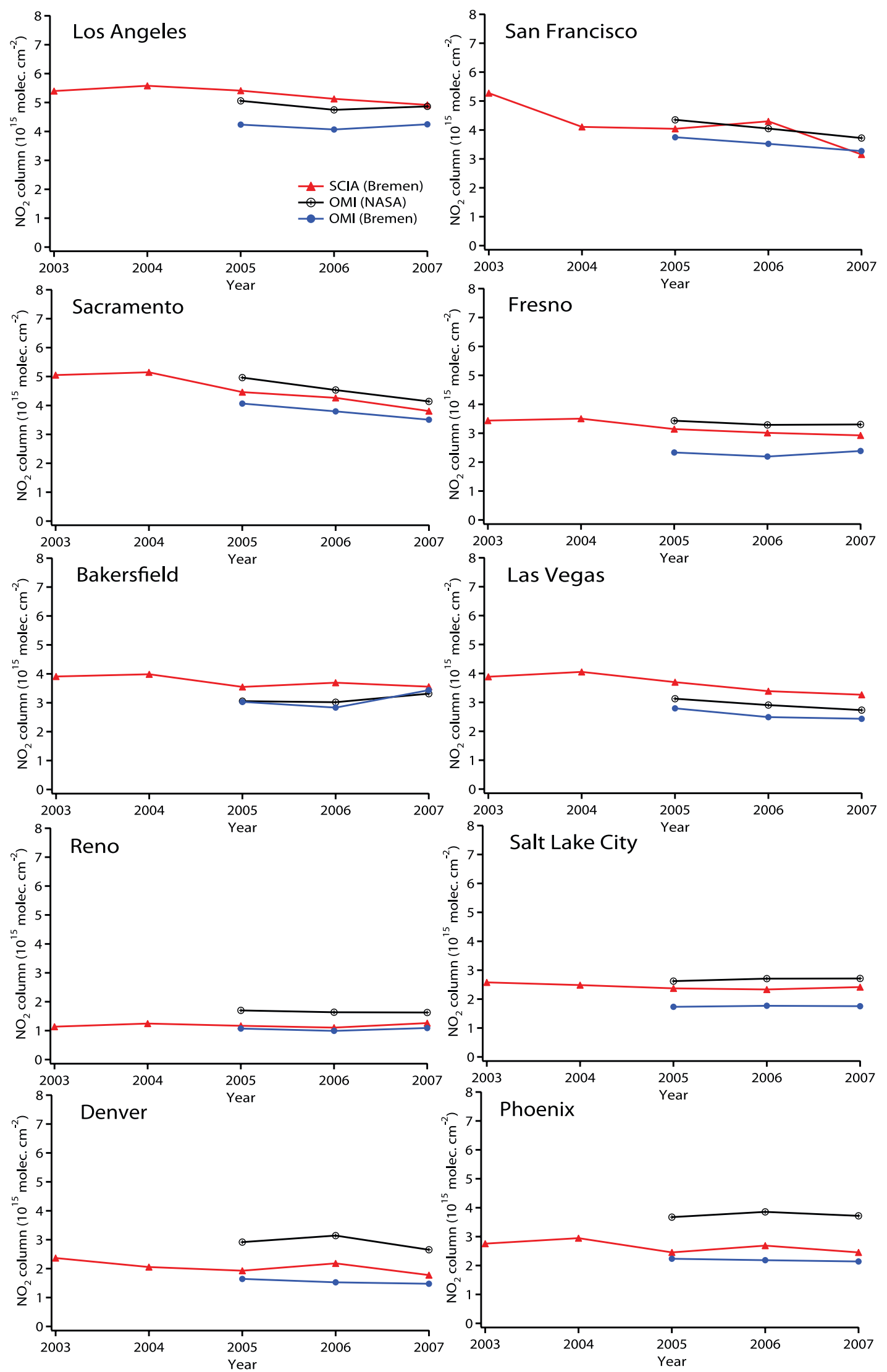

Figure 16. Trends in ozone season (May-September) average $\mathrm{NO}_{2}$ columns in the western U.S. city boxes. Solid lines with solid triangles, solid circles, and open circles with crosses denote UB SCIAMACHY, UB OMI, and NASA OMI, respectively. UB-SCIA 1, UB-OMI 1, and NASA-OMI 1 are used. See Table 1 for the description of these satellite data. 
Table 6. Satellite Trend Analysis and Linear Fit Coefficients

\begin{tabular}{|c|c|c|c|}
\hline $\begin{array}{c}\text { Averaging Box } \\
\text { Satellite Data Set } \\
\end{array}$ & $\begin{array}{c}\mathrm{NO}_{2} \text { Change } \\
\left(\% \mathrm{a}^{-1}\right)^{\mathrm{a}}\end{array}$ & $\begin{array}{l}\text { Slope, } s \pm \text { Standard Deviation, } \sigma \\
\quad\left(\text { molecule } \mathrm{cm}^{-2} \mathrm{a}^{-1}\right)(s / \sigma)\end{array}$ & $\begin{array}{l}\text { Correlation } \\
\text { Coefficient } \\
\end{array}$ \\
\hline \multicolumn{4}{|l|}{ C1: Los Angeles (Calif.) } \\
\hline SCIA (Bremen) & -2.53 & $-0.141 \pm 0.050[2.81]$ & -0.851 \\
\hline OMI (Bremen) & 0.14 & $0.006 \pm 0.100[0.06]$ & 0.060 \\
\hline OMI (NASA) & -1.93 & $-0.097 \pm 0.125[0.77]$ & -0.611 \\
\hline \multicolumn{4}{|c|}{ C2: San Francisco (Calif.) } \\
\hline SCIA (Bremen) & -8.13 & $-0.405 \pm 0.147[2.76]$ & -0.846 \\
\hline OMI (Bremen) & -6.38 & $-0.240 \pm 0.005[43.70]$ & -0.999 \\
\hline OMI (NASA) & -7.23 & $-0.315 \pm 0.007[45.45]$ & -0.999 \\
\hline \multicolumn{4}{|l|}{ C3: Sacramento (Calif.) } \\
\hline SCIA (Bremen) & -6.46 & $-0.337 \pm 0.061[5.49]$ & -0.954 \\
\hline OMI (Bremen) & -6.86 & $-0.279 \pm 0.005[53.65]$ & -0.999 \\
\hline OMI (NASA) & -8.31 & $-0.412 \pm 0.010[39.62]$ & -0.999 \\
\hline \multicolumn{4}{|l|}{ C4: Fresno (Calif.) } \\
\hline SCIA (Bremen) & -4.32 & $-0.151 \pm 0.033[4.63]$ & -0.937 \\
\hline OMI (Bremen) & 1.16 & $0.027 \pm 0.096[0.28]$ & 0.267 \\
\hline OMI (NASA) & -1.87 & $-0.064 \pm 0.046[1.38]$ & -0.810 \\
\hline \multicolumn{4}{|l|}{ C5: Bakersfield (Calif.) } \\
\hline SCIA (Bremen) & -2.54 & $-0.099 \pm 0.046[2.18]$ & -0.783 \\
\hline OMI (Bremen) & 7.01 & $0.203 \pm 0.230[0.88]$ & 0.661 \\
\hline OMI (NASA) & 4.28 & $0.129 \pm 0.095[1.35]$ & 0.804 \\
\hline \multicolumn{4}{|l|}{ C6: Las Vegas (Nev.) } \\
\hline SCIA (Bremen) & -4.73 & $-0.191 \pm 0.050[3.85]$ & -0.912 \\
\hline OMI (Bremen) & -6.57 & $-0.181 \pm 0.071[2.53]$ & -0.930 \\
\hline OMI (NASA) & -6.35 & $-0.198 \pm 0.014[13.75]$ & -0.997 \\
\hline \multicolumn{4}{|l|}{ C7: Reno (Nev.) } \\
\hline SCIA (Bremen) & 0.89 & $0.010 \pm 0.024[0.43]$ & 0.241 \\
\hline OMI (Bremen) & 0.91 & $0.010 \pm 0.052[0.18]$ & 0.181 \\
\hline OMI (NASA) & -2.10 & $-0.036 \pm 0.016[2.23]$ & -0.913 \\
\hline \multicolumn{4}{|c|}{ C8: Salt Lake City (Utah) } \\
\hline SCIA (Bremen) & -1.88 & $-0.048 \pm 0.022[2.16]$ & -0.780 \\
\hline OMI (Bremen) & 0.66 & $0.012 \pm 0.015[0.78]$ & 0.616 \\
\hline OMI (NASA) & 1.73 & $0.046 \pm 0.023[2.00]$ & 0.894 \\
\hline \multicolumn{4}{|l|}{ C9: Denver (Colo.) } \\
\hline SCIA (Bremen) & -4.63 & $-0.105 \pm 0.057[1.86]$ & -0.732 \\
\hline OMI (Bremen) & -5.15 & $-0.084 \pm 0.019[4.40]$ & -0.975 \\
\hline OMI (NASA) & -4.36 & $-0.133 \pm 0.206[0.64]$ & -0.540 \\
\hline \multicolumn{4}{|l|}{ C10: Phoenix (Ariz.) } \\
\hline SCIA (Bremen) & -3.04 & $-0.086 \pm 0.059[1.47]$ & -0.647 \\
\hline OMI (Bremen) & -2.11 & $-0.047 \pm 0.002[27.17]$ & -0.999 \\
\hline OMI (NASA) & 0.59 & $0.022 \pm 0.092[0.24]$ & 0.232 \\
\hline \multicolumn{4}{|l|}{ State: California } \\
\hline SCIA (Bremen) & -1.66 & $-0.048 \pm 0.018[2.61]$ & -0.657 \\
\hline OMI (Bremen) & -0.47 & $-0.011 \pm 0.044[0.25]$ & -0.243 \\
\hline OMI (NASA) & -2.50 & $-0.075 \pm 0.039[1.91]$ & -0.886 \\
\hline
\end{tabular}

${ }^{\mathrm{a}}$ Reference year for SCIAMACHY (OMI) = 2003 (2005).

mean satellite data over each western U.S. city. Table 6 gives detailed information on these trend analyses, including the average annual percentage change in $\mathrm{NO}_{2}$ column, the slope $(s)$ and standard deviation $(\sigma)$ of the linear fit, the absolute magnitude of $s / \sigma$ in brackets, and the correlation coefficient $(r)$ of the linear fit. It has been suggested [van $\operatorname{der} A$ et al., 2008] that $s / \sigma>2$ is a necessary criterion to obtain significant trend coefficients.

[64] Using this significance criterion, only the SCIAMACHY $\mathrm{NO}_{2}$ column data show a significant trend over Los Angeles, with a decline of $2.53 \%$ per year. The two OMI data sets do not show a clear declining trend between 2005 and 2007. van der A et al. [2008] also did not find clear trends over Los Angeles in their analysis of GOME and SCIAMACHY combined time series; the sign of their derived trend was negative but not statistically significant. As with Los Angeles, the satellite trends in Fresno and Bakersfield are significantly negative only with the SCIAMACHY data. The two OMI data sets exhibit increasing trends in Bakers- field and do not agree with each other in terms of the sign of the trend in Fresno. The three $\mathrm{NO}_{2}$ satellite data sets all agree that there are significant decreasing trends in San Francisco $\left(6.38-8.13 \% \mathrm{a}^{-1}\right)$, Sacramento (6.46$\left.8.31 \% \mathrm{a}^{-1}\right)$, and Las Vegas $\left(4.73-6.35 \% \mathrm{a}^{-1}\right)$. Reno, like Las Vegas, is located in Nevada, but does not demonstrate significant trends. In Salt Lake City, significant trends in SCIAMACHY $\left(-1.88 \% \mathrm{a}^{-1}\right)$ and in NASA OMI $\left(1.73 \% \mathrm{a}^{-1}\right)$ have opposite signs. Declines in $\mathrm{NO}_{2}$ columns over Denver from all three satellites are found $\left(4.63-5.15 \% \mathrm{a}^{-1}\right)$, although the trend in NASA OMI is not significant. There are no clear trends in Phoenix or in the smaller cities, whose trend data are not shown in Figure 16 and Table 6.

[65] For comparison, Figure 17 shows the May-Septemeptember average $\mathrm{NO}_{2}$ columns from the three satellites over the larger FCSJ box (P1b) and the total May-SepSeptember CEMS measured $\mathrm{NO}_{\mathrm{x}}$ emissions for the Four Corners and San Juan Power Plants for each year 2003-2007. The FCSJ CEMS $\mathrm{NO}_{\mathrm{x}}$ emissions and the 


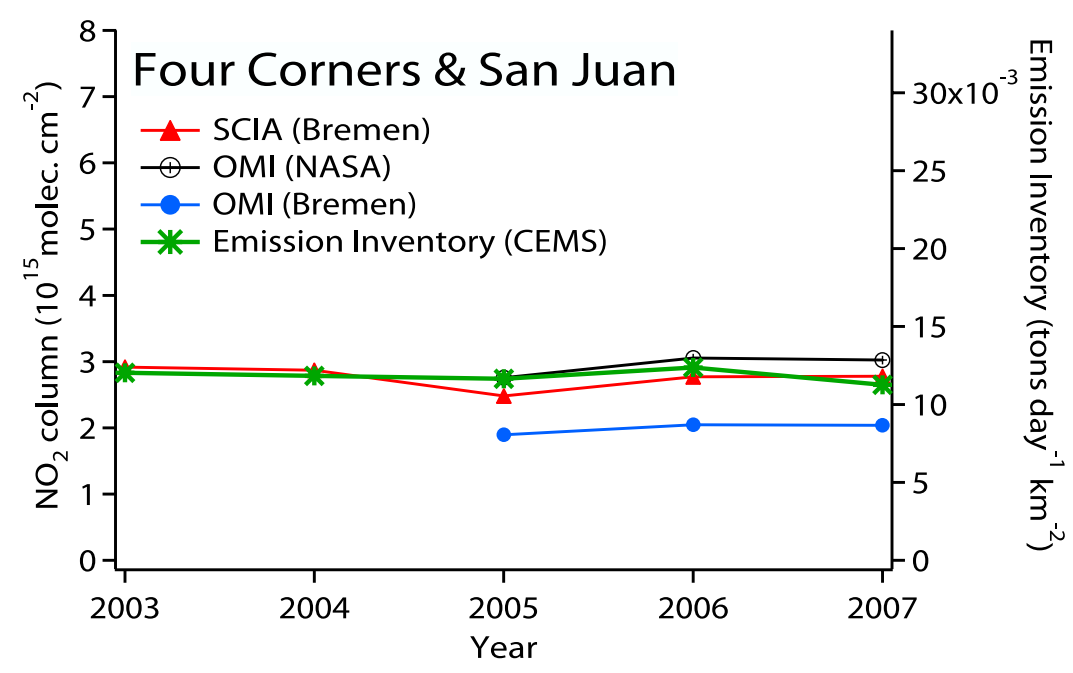

Figure 17. Trends in ozone season (May-September) average $\mathrm{NO}_{2}$ columns over the larger Four Corners and San Juan power plant box (P1b) from the UB SCIAMACHY (solid triangles), UB OMI (solid circles), and NASA OMI (circles with crosses) satellite data. Asterisks denote the total ozone season CEMS emissions (right-hand axis) for these two plants. UB-SCIA 1, UB-OMI 1, and NASA-OMI 1 are used. See Table 1 for the description of these satellite data.

$\mathrm{NO}_{2}$ columns from the satellite data sets are all nearly constant over this period, supporting the use of satellite $\mathrm{NO}_{2}$ columns in deriving $\mathrm{NO}_{\mathrm{x}}$ emission trends.

[66] Several limitations of this trend analysis should be kept in mind. First, the emission changes of interest are those between 1999 and 2005, while satellite trends could be derived only for the period between 2003 and 2007 because SCIAMACHY and OMI data are not available earlier. Second, the trends derived are based on only a few years of data, and could be affected by year-to-year variations in meteorology and corresponding chemistry and aerosol changes in addition to emission changes. Because the trends in $\mathrm{OMI} \mathrm{NO}$ columns are based on only 3 years of data, they should be interpreted with caution. Finally, there are significant systematic differences between the satellite data sets during the period of interest. For example, in Figures 16 and 17, the difference between NASA OMI and UB OMI $\mathrm{NO}_{2}$ columns is $\sim 1 \times 10^{15}$ molecules $\mathrm{cm}^{-2}$. This bias is often larger than the changes in $\mathrm{NO}_{2}$ columns within a given satellite data set for the period of interest. As discussed above, these retrieval differences arise from the different assumptions in the stratosphere-troposphere separation and the determination of AMF. Any individual set of data treated uniformly across the whole time period should give accurate trends, but small year-to-year changes in the satellite data still need to be interpreted with caution.

[67] In Figure 15, a decrease in $\mathrm{NO}_{\mathrm{x}}$ emissions from several California cities (C1-C5), Salt Lake City (C8), Phoenix (C10), and an increase in $\mathrm{NO}_{\mathrm{x}}$ emissions from Las Vegas (C6) could be inferred. The satellite $\mathrm{NO}_{2}$ column trend analysis of Figure 16 and Table 6 is consistent with $2005 \mathrm{NO}_{\mathrm{x}}$ emissions in San Francisco and Sacramento being 40-50\% lower than their 1999 levels. However, declining $\mathrm{NO}_{\mathrm{x}}$ emission trends in Los Angeles, Fresno, Bakersfield, Salt Lake City, and Phoenix are not confirmed by the $\mathrm{NO}_{2}$ column trend analysis. Furthermore, the column trend analysis does not show an increase in $\mathrm{NO}_{\mathrm{x}}$ emissions from Las Vegas, as implied by Figure 15. According to this analysis, discrepancies between the summer 2005 model simulations and satellite retrievals of $\mathrm{NO}_{2}$ columns in Los Angeles, Fresno, Bakersfield, Salt Lake City, Phoenix, and Las Vegas are attributed to factors other than $\mathrm{NO}_{\mathrm{x}}$ emission changes between 1999 and 2005.

[68] To understand if the lack of significant trends in $\mathrm{NO}_{2}$ columns over many of the urban sampling boxes is related to the small size of these boxes, we also analyzed satellite $\mathrm{NO}_{2}$ column trends over the much larger regions of six western U.S. states (Figure 18). The large discrepancy between OMI NASA and UB retrievals in Figure 18 is linked to the overall offset between the two products already visible in Figure 3. California is the only one of these states for which the satellites show a declining $\mathrm{NO}_{2}$ column trend, although the trends in the two OMI satellite retrievals are not statistically significant (see the end of Table 6). If the trend from the SCIAMACHY data is considered $(-1.66 \%$ $\left.\mathrm{a}^{-1}\right)$, a $10 \%$ reduction in $\mathrm{NO}_{\mathrm{x}}$ emissions from all of California between 1999 and 2005 may be inferred.

\subsubsection{Comparison of Bottom-Up $\mathrm{NO}_{\mathrm{x}}$ Inventory and Satellite $\mathrm{NO}_{2}$ Column Trends}

[69] We also examined trends in two state-level bottom-up inventory data sets, one for just the state of California and another for several western U.S. states. The trend in annual total California $\mathrm{NO}_{\mathrm{x}}$ emissions was derived from 2000, 2005, and 2010 data provided by the California Air Resources Board (CARB) [Air Resources Board and Office of Environmental Health and Hazard Assessment, 2006] and plotted in Figure 18. The trend in CARB emissions is $-3.47 \% \mathrm{a}^{-1}$, which is approximately twice as large as the trend in the SCIAMACHY $\mathrm{NO}_{2}$ column data $\left(-1.66 \% \mathrm{a}^{-1}\right)$.

[70] The second state-level bottom-up inventory trend analysis used on-road mobile emissions calculated from Federal Highway Administration statewide on-road gasoline and diesel fuel use (http://www.fhwa.dot.gov/policy/ohpi/ hss/hsspubs.htm) and measured fuel-specific emission factors [Ban-Weiss et al., 2008]. For this analysis, we assume that the trend in total $\mathrm{NO}_{\mathrm{x}}$ emissions from each state is driven 

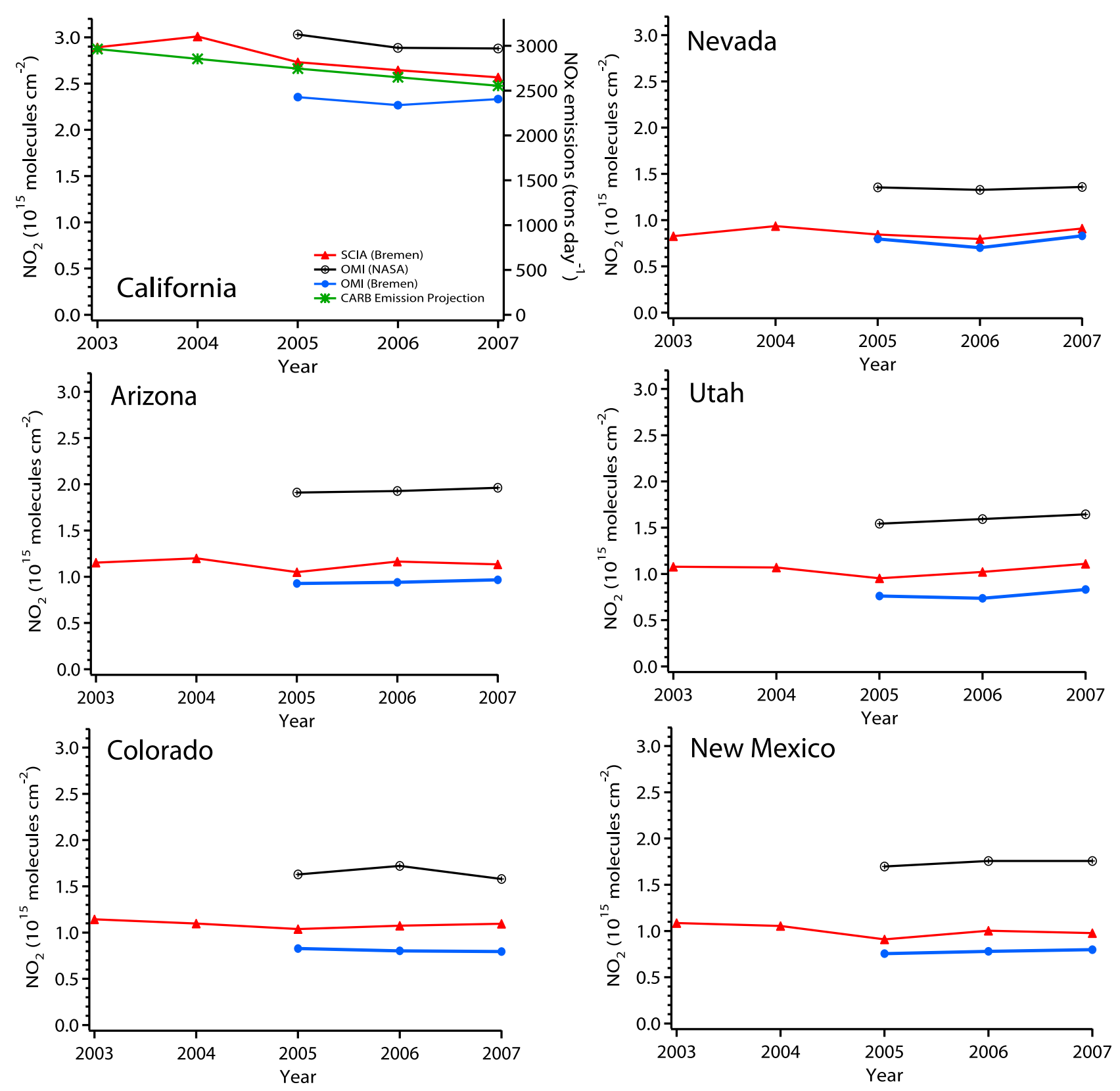

Figure 18. Trends in ozone season $\mathrm{NO}_{2}$ columns in the western U.S. states. Solid lines with solid triangles, solid circles, and open circles with crosses denote UB SCIAMACHY, UB OMI, and NASA OMI, respectively. Asterisks in the California box give the CARB emission inventory projections (righthand axis). UB-SCIA 1, UB-OMI 1, and NASA-OMI 1 are used. See Table 1 for the description of these satellite data.

by trends in on-road mobile emissions, which contribute the largest fraction to most states' total bottom-up $\mathrm{NO}_{\mathrm{x}}$ emissions. Table 7 shows that both gasoline and diesel fuel use increased between 1999 and 2005 in the six western U.S. states considered in Figure 18. Multiplying fuel-specific emission factors for 1999 and 2005 observed in roadside monitoring [Ban-Weiss et al., 2008] by each state's fuel use, we estimated the trend in each state's on-road mobile $\mathrm{NO}_{\mathrm{x}}$ emissions between 1999 and 2005 (Table 8).

[71] This fuel-based analysis indicates that 5 of the 6 states examined had declining on-road mobile $\mathrm{NO}_{\mathrm{x}}$ emissions during this period. This decline has been attributed primarily to reductions in emission factors for light-duty vehicles [Ban-Weiss et al., 2008; Bishop and Stedman, 2008]. According to this analysis, the lack of major on-road $\mathrm{NO}_{\mathrm{x}}$ emission changes in Nevada is caused by enhanced activity of heavy-duty vehicles, which have seen much smaller declines in emission factors than gasoline vehicles. The largest 1999-2005 relative and absolute reductions in onroad mobile $\mathrm{NO}_{\mathrm{x}}$ emissions occurred in California, $22.1 \%$ or about 400 tonnes $\mathrm{d}^{-1}$. The absolute 1999-2005 on-road $\mathrm{NO}_{\mathrm{x}}$ emissions change in California was eight times greater than that in Colorado, which had the second-largest absolute decrease (50 tonnes $\mathrm{d}^{-1}$ ) shown in Table 8 . This large 
Table 7. State Fuel Use in 1999 and 2005

\begin{tabular}{|c|c|c|c|c|c|c|}
\hline \multirow[b]{2}{*}{ State } & \multicolumn{2}{|c|}{$1999(\mathrm{~kL})$} & \multicolumn{2}{|c|}{$2005(\mathrm{~kL})$} & \multicolumn{2}{|c|}{ 1995-2005 Change (\%) } \\
\hline & Gasoline & Diesel & Gasoline & Diesel & Gasoline & Diesel \\
\hline Arizona & $8,891,428$ & $2,514,682$ & $10,705,001$ & $3,257,487$ & 20.4 & 29.5 \\
\hline California & $54,730,952$ & $9,349,197$ & $60,390,733$ & $11,600,031$ & 10.3 & 24.1 \\
\hline Colorado & $7,694,311$ & $1,702,178$ & $8,219,314$ & $2,097,186$ & 6.8 & 23.2 \\
\hline Nevada & $3,501,091$ & 995,902 & $4,316,127$ & $1,472,272$ & 23.3 & 47.8 \\
\hline New Mexico & $3,601,303$ & $1,517,129$ & $3,649,909$ & $1,823,683$ & 1.3 & 20.2 \\
\hline Utah & $3,790,481$ & $1,142,019$ & $3,961,460$ & $1,490,657$ & 4.5 & 30.5 \\
\hline
\end{tabular}

change might explain why, out of the 6 states examined here, SCIAMACHY sees $\mathrm{NO}_{2}$ column reductions only in California. It is encouraging that on-road $\mathrm{NO}_{\mathrm{x}}$ emissions in California might have been reduced, even though both fuel use and the California population increased $(7.92 \%$ between 2000 and 2007 (U.S. Census Bureau, Population Finder in American Factfinder, http://factfinder.census.gov/servlet/ SAFFPopulation?_submenuId=population_0\&_sse $=$ on, 2007)) during this time period. It is possible that the changes in on-road emissions in other states are smaller than the sensitivity of the satellite retrievals.

[72] A direct comparison of satellite-derived trends with those from bottom-up emission inventories is challenging, because both the magnitude of and trends in $\mathrm{NO}_{\mathrm{x}}$ emissions from non-power-plant point sources, off-road mobile sources, and other area-wide sources are more uncertain than those of on-road mobile sources (power plant emissions from the CEMS data set are well known and included here, although this sector is small in California). We assume that the fraction of on-road mobile sources to California state $\mathrm{NO}_{\mathrm{x}}$ emissions is $\sim 50 \%$, as is suggested by both the CARB and NEI inventories. Then the decline in total $\mathrm{NO}_{\mathrm{x}}$ emissions from California could be as small as $1.83 \% \mathrm{a}^{-1}$ if year-to-year changes in emissions from other sources are negligible (as is indicated by the CARB inventories) and as large as $3.67 \% \mathrm{a}^{-1}$ assuming that the declines in other sources are the same as those in on-road mobile emissions (using the fuel-based estimate). The smaller decline is very similar to the trend in the California SCIAMACHY $\mathrm{NO}_{2}$ column data (Table 6). The larger number agrees well with the CARB emissions projections [Air Resources Board and Office of Environmental Health and Hazard Assessment, 2006]. Using these two annual trend estimates to set the range, we estimate that the reductions in total $\mathrm{NO}_{\mathrm{x}}$ emissions in California between 1999 and 2005 are between $10 \%$ and $20 \%$.

\subsubsection{Biases in NEI99 $\mathrm{NO}_{\mathrm{x}}$ Emissions}

[73] In addition to emission changes between 1999 and 2005, a bias in the NEI99 $\mathrm{NO}_{\mathrm{x}}$ emissions could cause discrepancies between the 2005 satellite and model $\mathrm{NO}_{2}$ columns. We investigate this possibility by looking for consistency between NEI99, CARB, and fuel-based inventory representations of 1999 California $\mathrm{NO}_{\mathrm{x}}$ emissions.

[74] We first compare on-road mobile $\mathrm{NO}_{\mathrm{x}}$ emissions from 1999 and 2005 fuel-based estimates with the NEI99 inventory for each of the 6 western states of interest (Table 9). NEI99 on-road $\mathrm{NO}_{\mathrm{x}}$ emissions are 18\% higher than 1999 fuel-based estimates in California, while the NEI99 emissions in Nevada are 13\% lower than the 1999 fuel-based estimates. Differences between the NEI99 and 1999 fuelbased estimates for the other 4 states lie within this range. For comparison, NEI99 on-road $\mathrm{NO}_{\mathrm{x}}$ emissions are $51 \%$ higher and $12 \%$ lower than 2005 fuel-based estimates in California and Nevada, respectively.

[75] We next compared the 1999 California Air Resources Board inventory (CARB99) [Air Resources Board and Office of Environmental Health and Hazard Assessment, 2006] to NEI99 California $\mathrm{NO}_{x}$ emissions (Table 10). On-road mobile $\mathrm{NO}_{\mathrm{x}}$ emissions in CARB99 are 1807 tonnes/d, close to our fuel-based estimate (1822 tonnes/d) and 16\% lower than the NEI99 value (2141 tonnes/d). A more serious discrepancy exists in the NEI99 and CARB99 off-road mobile $\mathrm{NO}_{\mathrm{x}}$ emissions, with those from NEI99 $92 \%$ larger than those in CARB99. Stationary (point) and area-wide source $\mathrm{NO}_{\mathrm{x}}$ emissions in the two data sets agree well. Overall, total NEI99 $\mathrm{NO}_{\mathrm{x}}$ emissions are $35 \%$ higher than those in CARB99.

[76] Combining our California assessments of the NEI99 overestimate of $1999 \mathrm{NO}_{\mathrm{x}}$ emissions and $\mathrm{NO}_{2}$ column decreases between 1999 and 2005, we estimate that California NEI99 emissions must be reduced by $\sim 50 \%$ to properly represent California's 2005 emissions. In other words, both

Table 8. Fuel-Based On-Road Mobile $\mathrm{NO}_{\mathrm{x}}$ Emissions in 1999 and $2005^{\mathrm{a}}$

\begin{tabular}{|c|c|c|c|c|c|c|c|c|c|}
\hline \multirow[b]{2}{*}{ State } & \multicolumn{3}{|c|}{$1999(\mathrm{t} / \mathrm{d})$} & \multicolumn{3}{|c|}{$2005(\mathrm{t} / \mathrm{d})$} & \multicolumn{3}{|c|}{ 1999-2005 Change (\%) } \\
\hline & Gasoline & Diesel & Total & Gasoline & Diesel & Total & Gasoline & Diesel & Total \\
\hline Arizona & 138 & 261 & 399 & 80 & 273 & 353 & -42.0 & 4.6 & -11.5 \\
\hline California & 851 & 971 & 1822 & 449 & 972 & 1421 & -47.2 & 0.1 & -22.0 \\
\hline Colorado & 120 & 177 & 297 & 61 & 176 & 237 & -49.2 & -0.6 & -20.2 \\
\hline Nevada & 54 & 103 & 157 & 32 & 123 & 155 & -40.7 & 19.4 & -1.3 \\
\hline New Mexico & 56 & 158 & 214 & 27 & 153 & 180 & -51.8 & -3.2 & -15.9 \\
\hline Utah & 59 & 119 & 178 & 29 & 125 & 154 & -50.8 & 5.0 & -13.5 \\
\hline
\end{tabular}

${ }^{a}$ Derived using gasoline and diesel emission factors per unit mass of fuel burned reported by Ban-Weiss et al. [2008] and linearly interpolated to the years 1999 and 2005. Emissions are given as metric tons per day. 
Table 9. On-Road Mobile $\mathrm{NO}_{\mathrm{x}}$ Emissions From Fuel-Based Estimate and From NEI99 ${ }^{\text {a }}$

\begin{tabular}{llllllll}
\hline & \multicolumn{3}{c}{$1999(\mathrm{t} / \mathrm{d})$} & & \multicolumn{3}{c}{$2005(\mathrm{t} / \mathrm{d})$} \\
\cline { 2 - 4 } \cline { 7 - 8 } \multicolumn{1}{c}{ State } & FB & NEI99 & Dif $(\%)$ & & FB & NEI99 & Dif (\%) \\
\hline Arizona & 399 & 415 & 4 & & 353 & 415 & 17 \\
California & 1822 & 2141 & 18 & & 1421 & 2141 & 51 \\
Colorado & 297 & 308 & 4 & & 237 & 308 & 30 \\
Nevada & 157 & 137 & -13 & & 155 & 137 & -12 \\
New Mexico & 214 & 194 & -9 & & 180 & 194 & 8 \\
Utah & 178 & 166 & -7 & & 154 & 166 & 8 \\
\hline
\end{tabular}

${ }^{\mathrm{a}}$ Emissions are given as metric tons per day. Dif $(\%)=(\mathrm{NEI} 99-\mathrm{FB})$ $\mathrm{FB} \times 100$.

uncertainties in the NEI99 and 1999-2005 emission changes appear to contribute to the model-satellite discrepancies in $2005 \mathrm{NO}_{2}$ columns over California urban areas.

\section{Conclusions}

[77] Model-simulated $\mathrm{NO}_{2}$ columns over western U.S. power plants are used to validate satellite $\mathrm{NO}_{2}$ column retrievals, the first time such a method has been attempted. Direct CEMS observations of $\mathrm{NO}_{\mathrm{x}}$ emissions at most U.S. power plants reduce the uncertainties in simulated $\mathrm{NO}_{2}$ columns and provide a quantitative basis for evaluating satellite observations. The model-calculated and satelliteobserved $\mathrm{NO}_{2}$ columns show good agreement over regions dominated by power plant $\mathrm{NO}_{\mathrm{x}}$ emissions. Minimizing emission errors in the model calculations over power plants allows us to explore the sensitivity of the modeled and satellite-retrieved columns to other assumptions.

[78] For the Four Corners and San Juan power plants, model simulations of $\mathrm{NO}_{2}$ columns driven by CEMS observations of actual hourly $\mathrm{NO}_{\mathrm{x}}$ emissions show better agreement with satellite columns than model calculations using the more typical input of annual or monthly mean emissions adjusted with EPA default diurnal factors. In other words, hourly and daily fluctuations in power plant $\mathrm{NO}_{\mathrm{x}}$ emissions can differ significantly from monthly averages, and we infer that satellite observations can detect such variability in the emissions of an isolated point source.

[79] The good model-satellite agreement for western U.S. power plants supports the use of satellite data in the improvement of urban emission inventories, which inherently have more uncertainty than those of power plants. In contrast to areas dominated by power plant emissions, the model and satellite $\mathrm{NO}_{2}$ columns exhibit significant discrepancies over western U.S. urban areas. The model $\mathrm{NO}_{2}$ columns over several California cities are twice as large as the satellite-retrieved columns, a difference beyond the range of uncertainties derived from numerous sensitivity tests of both the satellite retrievals and model simulations. The discrepancy between the model and the satellite over urban areas can be attributed to uncertainties in both the NEI99 $\mathrm{NO}_{\mathrm{x}}$ emissions used to drive the model and $\mathrm{NO}_{\mathrm{x}}$ emission changes between 1999 and 2005, especially in California. This is a novel example of a successful application of satellite data to evaluate and improve urban emission inventories. Satellite $\mathrm{NO}_{2}$ columns data are uniquely suited to monitoring integrated changes in urbanscale $\mathrm{NO}_{\mathrm{x}}$ emissions.

[80] Over regions dominated by power plant $\mathrm{NO}_{\mathrm{x}}$ emissions, all three satellite data sets show agreement with the model results and with each other, with differences of no more than $1.5 \times 10^{15}$ molecules $\mathrm{cm}^{-2}$ for data averages ranging from 14 days to 3 months. This level of agreement has not always been achieved in previous satellite retrieval intercomparisons [van Noije et al., 2006]. In areas dominated by power plant emissions, 2005 SCIAMACHY and OMI $\mathrm{NO}_{2}$ column retrievals by the University of Bremen team tend to be somewhat lower than the model results, while the OMI retrievals by the NASA team are the same as or slightly higher than the model simulations. It appears that the differences between the UB and NASA retrievals are due to different methods for separating stratospheric and tropospheric columns and alternative treatments of $\mathrm{NO}_{2}$ vertical profile shape, aerosols, and partially cloudy scenes in the AMF calculations.

[81] The WRF-Chem model is still evolving. For example, the current version does not include day-of-week variations in $\mathrm{NO}_{\mathrm{x}}$ emissions from sources other than power plants, $\mathrm{NO}_{\mathrm{x}}$ emissions from lightning, or a satisfactory treatment of aerosol sources (including dust emissions and primary anthropogenic particulates) and chemical processing (including secondary organic aerosol formation). All of these factors could affect WRF-Chem calculations of both the shape of the $\mathrm{NO}_{2}$ vertical profile, which could in turn affect the satellite retrievals, and the $\mathrm{NO}_{2}$ vertical column.

[82] Our study assumes that the changes in $\mathrm{NO}_{2}$ columns are directly proportional to changes in $\mathrm{NO}_{\mathrm{x}}$ emissions, which may not always be true. For this reason we presented only summertime data here, since transport effects on the total $\mathrm{NO}_{2}$ column are smaller than in winter. As a recent study has shown [Napelenok et al., 2008], an inverse method using a regional chemical-transport model could explicitly account for chemical processing in calculating the relationship between $\mathrm{NO}_{2}$ columns and $\mathrm{NO}_{\mathrm{x}}$ emissions. Such techniques should provide a complementary approach to the one we demonstrate here.

[83] Acknowledgments. Many thanks go to G. Grell, S. Peckham, M. Salzmann, B. Skamarock, and R. Portmann for numerous discussions about the WRF-Chem model. The authors thank R. Harley for assistance with the emission trends analysis. Parts of the satellite retrievals used in this study were funded by the University of Bremen and the European Union through the ACCENT project. The Dutch-Finnish built OMI is part of the

Table 10. Comparison of CARB99 and NEI99 Inventories for California $^{\mathrm{a}}$

\begin{tabular}{lllc}
\hline \multicolumn{1}{c}{ Source Type } & $\begin{array}{c}\text { CARB99 } \\
(\mathrm{t} / \mathrm{d})\end{array}$ & $\begin{array}{c}\text { NEI99 } \\
(\mathrm{t} / \mathrm{d})\end{array}$ & $\begin{array}{c}\text { Our Study }^{\mathrm{b}} \\
(\mathrm{t} / \mathrm{d})\end{array}$ \\
\hline On-road mobile & 1807 & 2141 & 1822 \\
Other mobile & 931 & 1791 & \\
Stationary and area-wide sources & 644 & 622 & \\
All sources & 3382 & 4554 & \\
\hline
\end{tabular}

${ }^{\mathrm{a} C A R B 99}$ is generated by interpolating data in Table 4.2 in Air Resources Board and Office of Environmental Health and Hazard Assessment, State of California, Review of the California ambient air quality standard for nitrogen dioxide, 2006, draft technical support document available at ftp://ftp.arb.ca.gov/carbis/research/aaqs/no2rs/ no2tech-draft.pdf. Emissions are given as metric tons per day.

${ }^{\mathrm{b}}$ Estimation based on fuel use and observed emission factors. 
NASA EOS Aura satellite payload. The OMI project is managed by NIVR and KNMI in the Netherlands. The authors wish to acknowledge support from NOAA's Health of the Atmosphere research program.

\section{References}

Ackermann, I. J., H. Hass, M. Memmesheimer, A. Ebel, F. S. Binkowski, and U. Shankar (1998), Modal aerosol dynamics model for Europe: Development and first applications, Atmos. Environ., 32(17), $2981-$ 2999, doi:10.1016/S1352-2310(98)00006-5.

Air Resources Board and Office of Environmental Health and Hazard Assessment (2006), Review of the California ambient air quality standard for nitrogen dioxide, report, Calif. Environ. Prot. Agency, Sacramento. (Available at ftp://ftp.arb.ca.gov/carbis/research/aaqs/no2rs/ no2tech-draft.pdf)

Ban-Weiss, G. A., J. P. McLaughlin, R. A. Harley, M. M. Lunden, T. W. Kirchstetter, A. J. Kean, A. W. Strawa, E. D. Stevenson, and G. R. Kendall (2008), Long-term changes in emissions of nitrogen oxides and particulate matter from on-road gasoline and diesel vehicles, Atmos. Environ., 42(2), 220-232, doi:10.1016/j.atmosenv.2007.09.049.

Beirle, S., U. Platt, M. Wenig, and T. Wagner (2003), Weekly cycle of $\mathrm{NO}_{2}$ by GOME measurements: A signature of anthropogenic sources, Atmos. Chem. Phys., 3, 2225-2232.

Beirle, S., U. Platt, M. Wenig, and T. Wagner (2004), Highly resolved global distribution of tropospheric $\mathrm{NO}_{2}$ using GOME narrow swath mode data, Atmos. Chem. Phys., 4, 1913-1924.

Bertram, T. H., A. Heckel, A. Richter, J. P. Burrows, and R. C. Cohen (2005), Satellite measurements of daily variations in soil $\mathrm{NO}_{\mathrm{x}}$ emissions, Geophys. Res. Lett., 32, L24812, doi:10.1029/2005GL024640.

Bey, I., D. Jacob, R. Yantosca, J. Logan, B. Field, A. Fiore, Q. Li, H. Liu, L. Mickley, and M. Schultz (2001), Global modeling of tropospheric chemistry with assimilated meteorology: Model description and evaluation, J. Geophys. Res., 106(D19), 23,073-23,095, doi:10.1029/ 2001JD000807.

Bishop, G. A., and D. H. Stedman (2008), A decade of on-road emissions measurements, Environ. Sci. Technol., 42(5), 1651-1656, doi:10.1021/ es702413b.

Boersma, K. F., H. J. Eskes, and E. J. Brinksma (2004), Error analysis for tropospheric $\mathrm{NO}_{2}$ retrieval from space, J. Geophys. Res., 109, D04311, doi:10.1029/2003JD003962.

Bovensmann, J., J. P. Burrows, M. Buchwitz, J. Frerick, S. Noel, V. V. Rozanov, K. V. Chance, and A. P. H. Goede (1999), SCIAMACHY: Mission objectives and measurement modes, J. Atmos. Sci., 56, 127 150, doi:10.1175/1520-0469(1999)056<0127:SMOAMM>2.0.CO;2.

Bucsela, E. J., E. A. Celarier, M. O. Wenig, J. F. Gleason, J. P. Veefkind, K. F. Boersma, and E. Brinksma (2006), Algorithm for $\mathrm{NO}_{2}$ vertical column retrieval from the ozone monitoring instrument, IEEE Trans. Geosci. Remote Sens., 44, 1245-1258, doi:10.1109/TGRS.2005.863715.

Bucsela, E. J., et al. (2008), Comparison of tropospheric $\mathrm{NO}_{2}$ from in situ aircraft measurements with near-real-time and standard product data from OMI, J. Geophys. Res., 113, D16S31, doi:10.1029/2007JD008838.

Burrows, J. P., et al. (1999), The global ozone monitoring experiment (GOME): Mission concept and first scientific results, J. Atmos. Sci. 56, $151-175$, doi:10.1175/1520-0469(1999)056<0151:TGOMEG $>2.0$. $\mathrm{CO} ; 2$.

Calvert, J. G., R. Atkinson, K. H. Becker, R. M. Kames, J. H. Seinfeld, T. H. Wallington, and G. Yarwood (2002), The Mechanisms of Atmospheric Oxidation of Aromatic Hydrocarbons, 566 pp., Oxford Univ. Press, Oxford, U. K.

Celarier, E. A., et al. (2008), Validation of Ozone Monitoring Instrument nitrogen dioxide columns, J. Geophys. Res., 113, D15S15, doi:10.1029/ 2007JD008908.

Chance, K. (Ed.) (2002), OMI trace gas algorithms, version 2.0, ATBDOMI-04, 78 pp., NASA Goddard Space Flight Cent., Greenbelt, Md. (Available at http://eospso.gsfc.nasa.gov/eos_homepage/for_scientists/ atbd/viewInstrument.php?instrument=13)

Chen, F., and J. Dudhia (2001), Coupling an advanced land-surface(hydrology model with the Penn State(NCAR MM5 modeling system. Part I: Model description and implementation, Mon. Weather Rev., 129, 569-585, doi:10.1175/1520-0493(2001)129<0569:CAALSH $>2.0$. CO;2.

Dave, J. V. (1965), Multiple scattering in a non-homogeneous, Rayleigh atmosphere, J. Atmos. Sci., 22, 273-279, doi:10.1175/1520-0469(1965) 022<0273:MSIANH $>2.0$. CO;2.

Dentener, F., et al. (2006), Nitrogen and sulfur deposition on regional and global scales: A multimodel evaluation, Global Biogeochem. Cycles, 20 GB4003, doi:10.1029/2005GB002672.

Dudhia, J. (1989), Numerical study of convection observed during the winter monsoon experiment using a mesoscale two-dimensional model, J. Atmos. Sci., 46, 3077-3107, doi:10.1175/1520-0469(1989)046<3077: NSOCOD $>2.0 . \mathrm{CO} ; 2$.
Dyer, A. J., and B. B. Hicks (1970), Flux-gradient relationships in the constant flux layer, Q. J. R. Meteorol. Soc., 96, 715-721, doi:10.1002/ qj.49709641012.

Frost, G. J., et al. (2006), Effects of changing power plant $\mathrm{NO}_{\mathrm{x}}$ emissions on ozone in the eastern United States: Proof of concept, J. Geophys. Res., 111, D12306, doi:10.1029/2005JD006354.

Galloway, J. N., et al. (2004), Nitrogen cycles: Past, present, and future, Biogeochemistry, 70(2), 153-226, doi:10.1007/s10533-004-0370-0.

Geiger, H., I. Barnes, I. Bejan, T. Benter, and M. Spittler (2003), The tropospheric degradation of isoprene: An updated module for the regional atmospheric chemistry mechanism, Atmos. Environ., 37(11), 1503-1519, doi:10.1016/S1352-2310(02)01047-6.

Grell, G. A., and D. Devenyi (2002), A generalized approach to parameterizing convection combining ensemble and data assimilation techniques, Geophys. Res. Lett., 29(14), 1693, doi:10.1029/2002GL015311.

Grell, G. A., S. E. Peckham, R. Schmitz, S. A. McKeen, G. Frost, W. C. Skamarock, and B. Eder (2005), Fully coupled "online" chemistry within the WRF model, Atmos. Environ., 39(37), 6957-6975, doi:10.1016/ j.atmosenv.2005.04.027

Harley, R. A., L. C. Marr, J. K. Lehner, and S. N. Giddings (2005), Changes in motor vehicle emissions in diurnal to decadal time scales and effects on atmospheric composition, Environ. Sci. Technol., 39(14), 5356-5362, doi:10.1021/es048172+.

Hong, S.-Y., J. Dudhia, and S.-H. Chen (2004), A revised approach to ice microphysical processes for the bulk parameterization of clouds and precipitation, Mon. Weather Rev., 132, 103-120, doi:10.1175/15200493(2004)132<0103:ARATIM>2.0.CO;2

Hong, S.-Y., Y. Noh, and J. Dudhia (2006), a new vertical diffusion package with an explicit treatment of entrainment processes, Mon. Weather Rev, 134, 2318-2341, doi:10.1175/MWR3199.1.

Horowitz, L. W., et al. (2003), A global simulation of tropospheric ozone and related tracers: Description and evaluation of MOZART, version 2 J. Geophys. Res., 108(D24), 4784, doi:10.1029/2002JD002853.

Jaeglé, L., L. Steinberger, R. V. Martin, and K. Chance (2005), Global partitioning of $\mathrm{NO}_{x}$ sources using satellite observations: Relative roles of fossil fuel combustion, biomass burning and soil emissions, Faraday Discuss., 130, 407-423, doi:10.1039/b502128f.

Kim, S.-W., A. Heckel, S. A. McKeen, G. J. Frost, E.-Y. Hsie, M. K. Trainer, A. Richter, J. P. Burrows, S. E. Peckham, and G. A. Grell (2006), Satellite-observed U.S. power plant $\mathrm{NO}_{\mathrm{x}}$ emission reductions and their impact on air quality, Geophys. Res. Lett., 33, L22812, doi:10.1029/2006GL027749.

Koelemeijer, R. B. A., J. F. de Haan, and P. Stammes (2003), A database of spectral surface reflectivity in the range $335-772 \mathrm{~nm}$ derived from 5.5 years of GOME observations, J. Geophys. Res., 108(D2), 4070, doi:10.1029/2002JD002429.

Konovalov, I. B., M. Beekman, A. Richter, and J. P. Burrows (2006), Inverse modelling of the spatial distribution of $\mathrm{NO}_{\mathrm{x}}$ emissions on a continental scale using satellite data, Atmos. Chem. Phys., 6, 1747-1770.

Levelt, P. F., G. H. J. van den Oord, M. R. Dobber, A. Malkki, H. Visser, J. de Vries, P. Stammes, J. Lundell, and H. Saari (2006), The ozone monitoring instrument, IEEE Trans. Geosci. Remote Sens., 44, 1093-1101, doi:10.1109/TGRS.2006.872333.

Madronich, S. (1987), Photodissociation in the atmosphere: 1. Actinic flux and the effects of ground reflections and clouds, J. Geophys. Res., 92(D8), 9740-9752, doi:10.1029/JD092iD08p09740.

Martin, R. V., D. J. Jacob, R. M. Yantosca, M. Chin, and P. Ginoux (2003a), Global and regional decreases in tropospheric oxidants from photochemical effects of aerosols, J. Geophys. Res., 108(D3), 4097, doi:10.1029/ 2002JD002622.

Martin, R. V., D. J. Jacob, K. Chance, T. P. Kurosu, P. I. Palmer, and M. J. Evans (2003b), Global inventory of nitrogen oxides emissions constrained by space-based observations of $\mathrm{NO}_{2}$ columns, J. Geophys. Res., 108(D17), 4537, doi:10.1029/2003JD003453.

Martin, R. V., B. Sauvage, I. Folkins, C. E. Sioris, C. Boone, P. Bernath, and J. Ziemke (2007), Space-based constraints on the production of nitric oxide by lightning, J. Geophys. Res., 112, D09309, doi:10.1029/ 2006JD007831.

McKeen, S. A., G. Wotawa, D. D. Parrish, J. S. Holloway, M. P. Buhr, G. Hubler, F. C. Fehsenfeld, and J. F. Meagher (2002), Ozone production from Canadian wildfires during June and July of 1995, J. Geophys. Res., 107(D14), 4192, doi:10.1029/2001JD000697.

Mlawer, E. J., S. J. Taubman, P. D. Brown, M. J. Iacono, and S. A. Clough (1997), Radiative transfer for inhomogeneous atmosphere: RRTM, a validated correlated-k model for the long-wave, J. Geophys. Res., 102(D14), 16,663-16,682, doi:10.1029/97JD00237.

Napelenok, S. L., R. W. Pinder, A. B. Gilliland, and R. V. Martin (2008), A method for evaluating spatially resolved $\mathrm{NO}_{\mathrm{x}}$ emissions using Kalman filter inversion, direct sensitivities, and space-based $\mathrm{NO}_{2}$ observations, Atmos. Chem. Phys. Discuss., 8, 6469-6499. 
Orlando, J. J., G. S. Tyndall, S. B. Bertman, W. Chen, and J. B. Burkholder (2002), Rate coefficient for the reaction of $\mathrm{OH}$ with $\mathrm{CH}_{2}=\mathrm{C}\left(\mathrm{CH}_{3}\right) \mathrm{C}$ (O)OONO 2 (MPAN), Atmos. Environ., 36(11), 1895-1900, doi:10.1016/ S1352-2310(02)00090-0.

Palmer, P. I., D. J. Jacob, K. Chance, R. V. Martin, R. J. D. Spurr, T. P. Kurosu, I. Bey, R. Yantosca, and A. Fiore (2001), Air-mass factor formulation for spectroscopic measurements from satellites: Application to formaldehyde retrievals from the Global Ozone Monitoring Experiment, J. Geophys. Res., 106(D13), 14,539-14,550, doi:10.1029/ 2000JD900772.

Park, R. J., D. J. Jacob, B. D. Field, R. M. Yantosca, and M. Chin (2004), Natural and transboundary pollution influences on sulfate-nitrate-ammonium aerosols in the United States: Implications for policy, J. Geophys. Res., 109, D15204, doi:10.1029/2003JD004473.

Paulson, C. A. (1970), The mathematical representation of wind speed and temperature profiles in the unstable atmospheric surface layer, $\mathrm{J} . \mathrm{Appl}$. Meteorol., 9, 857-861, doi:10.1175/1520-0450(1970)009<0857: TMROWS $>2.0 . \mathrm{CO} ; 2$.

Richter, A., and J. P. Burrows (2002), Tropospheric $\mathrm{NO}_{2}$ from GOME measurements, Adv. Space Res., 29, 1673-1683, doi:10.1016/S02731177(02)00100-X

Richter, A., J. P. Burrows, H. Nub, C. Granier, and U. Niemeier (2005), Increase in tropospheric nitrogen dioxide levels over China observed from space, Nature, 437, 129-132, doi:10.1038/nature04092.

Rozanov, V., D. Diebel, R. Spurr, and J. Burrows (1997), GOMETRAN: A radiative transfer model for the satellite project GOME, the plane-parallel version, J. Geophys. Res., 102(D14), 16,683-16,695, doi:10.1029/ 96JD01535.

Ryerson, T. B., et al. (1998), Emissions lifetimes and ozone formation in power plant plumes, J. Geophys. Res., 103(D17), 22,569-22,583, doi:10.1029/98JD01620.

Sander, S. P., et al. (2006), Chemical kinetics and photochemical data for use in atmospheric studies evaluation number 15, JPL Publ., 06-2, $523 \mathrm{pp}$.

Schaub, D., K. F. Boersma, J. Keller, D. Folini, D. Brunner, B. Buchmann, H. Berresheim, and J. Staehelin (2007), SCIAMACHY tropospheric $\mathrm{NO}_{2}$ over Switzerland: Estimates of $\mathrm{NO}_{\mathrm{x}}$ lifetimes and impact of the complex Alpine topography on the retrieval, Atmos. Chem. Phys., 7, 5971-5987.

Schell, B., I. J. Ackermann, H. Hass, F. S. Binkowski, and A. Ebel (2001), Modeling the formation of secondary organic aerosol within a comprehensive air quality model system, J. Geophys. Res., 106(D22), 28,275-28,293, doi:10.1029/2001JD000384.

Shettle, E. P., and R. W. Fenn (1979), Models for the aerosols of the lower atmosphere and the effects of humidity variations on their optical properties, Rep. AFGL TR-79-0214, 94 pp., Air Force Geophys. Lab., Bedford, Mass.

Skamarock, W. C. (2006), Positive-definite and monotonic limiters for unrestricted-time-step transport schemes, Mon. Weather Rev., 134, 2241-2250, doi:10.1175/MWR3170.1.

Skamarock, W. C., J. B. Klemp, J. Dudhia, D. O. Gill, D. M. Barker, W. Wang, and J. G. Powers (2007), A description of the advanced research WRF version 2, NCAR Tech. Note NCAR/TN-468+STR, 100 pp., UCAR Commun., Boulder, Colo.

Solomon, S., R. W. Portmann, R. W. Sanders, J. S. Daniel, W. Madsen, B. Bartram, and E. G. Dutton (1999), On the role of nitrogen dioxide in the absorption of solar radiation, J. Geophys. Res., 104(D10), 12,047-12,058, doi:10.1029/1999JD900035.
Stockwell, W. R., P. Middleton, J. S. Chang, and X. Tang (1990), The second generation regional acid deposition model chemical mechanism for regional air quality modeling, J. Geophys. Res., 95(D10), 16,343-16,367, doi:10.1029/JD095iD10p16343.

Stockwell, W. R., F. Kirchner, M. Kuhm, and S. Seefeld (1997), A new mechanism for regional atmospheric chemistry modeling, J. Geophys. Res., 102(D22), 25,847-25,879, doi:10.1029/97JD00849.

Tyndall, G., R. Cox, C. Granier, R. Lesclaux, G. Moortgat, M. Pilling, A. Racishankara, and T. Wallington (2001), Atmospheric chemistry of small organic peroxy radicals, J. Geophys. Res., 106(D11), 12,157-12,182, doi: 10.1029/2000JD900746.

U.S. Environmental Protection Agency (2004), $\mathrm{NO}_{\mathrm{x}}$ Budget Trading Program 2003 progress and compliance report, Rep. EPA-430-R-04-010, 28 pp., Clean Air Markets Div., Off. of Air and Radiat., Washington, D. C. (Available at http://www.epa.gov/airmarkt/progress/docs/noxreport03. pdf)

van der A, R. J., D. H. M. U. Peters, H. Eskes, K. F. Boersma, M. Van Roozendael, I. De Smedt, and H. M. Kelder (2006), Detection of the trend and seasonal variation in tropospheric $\mathrm{NO}_{2}$ over China, J. Geophys. Res., 111, D12317, doi:10.1029/2005JD006594.

van $\operatorname{der}$ A, R. J., H. J. Eskes, K. F. Boersma, T. P. C. van Noije, M. Van Roozendael, I. De Smedt, H. M. U. D.Peters, and E. W. Meijer (2008), Trends, seasonal variability and dominant $\mathrm{NO}_{\mathrm{x}}$ source derived from a ten year record of $\mathrm{NO}_{2}$ measured from space, J. Geophys. Res., 113, D04302, doi:10.1029/2007JD009021.

van Noije, T. P. C., H. J. Eskes, F. J. Dentener, D. S. Stevenson, K. Ellingsen, M. G. Schultz, and O. Wild (2006), Multi-model ensemble simulations of tropospheric $\mathrm{NO}_{2}$ compared with GOME retrievals for the year 2000, Atmos. Chem. Phys., 6, 2943-2979.

Wenig, M. O., A. M. Cede, E. J. Bucsela, E. A. Celarier, K. F. Boersma J. P. Veefkind, E. J. Brinksma, J. F. Gleason, and J. R. Herman (2008), Validation of OMI tropospheric $\mathrm{NO}_{2}$ column densities using direct-Sun mode Brewer measurements at NASA Goddard Space Flight Center, J. Geophys. Res., 113, D16S45, doi:10.1029/2007JD008988.

Wicker, L. J., and W. C. Skamarock (2002), Time splitting methods for elastic models using forward time schemes, Mon. Weather Rev., 130, 2088-2097, doi:10.1175/1520-0493(2002)130<2088:TSMFEM $>2$.0. $\mathrm{CO} ; 2$.

Yevich, R., and J. A. Logan (2003), An assessment of biofuel use and burning of agricultural waste in the developing world, Global Biogeochem. Cycles, 17(4), 1095, doi:10.1029/2002GB001952.

J. P. Burrows, Center for Ecology and Hydrology, Maclean Building, Benson Lane, Crowmarsh Gifford, Wallingford OX10 8BB, UK.

G. J. Frost, C. Granier, E.-Y. Hsie, S.-W. Kim, S. McKeen, and M. Trainer, Chemical Sciences Division, Earth System Research Laboratory, NOAA, 325 Broadway, R/CSD4, Boulder, CO 80305, USA. (siwan.kim@noaa.gov) J. Gleason, Laboratory for Atmospheres, NASA Goddard Space Flight Center, Mail Code 613, Greenbelt, MD 20771, USA.

A. Heckel, Department of Geography, Swansea University, Swansea SA2 8PP, UK.

A. Richter, Institute of Environmental Physics, University of Bremen, FB1, Postfach 330440, D-28334 Bremen, Germany. 